\title{
Genomic imprinting disorders: lessons on how genome, epigenome and environment interact
}

David Monk ${ }^{1}$, Deborah J. G. Mackay ${ }^{2}$, Thomas Eggermann ${ }^{3}$, Eamonn R. Maher ${ }^{4}$ and Andrea Riccio ${ }^{5^{*}}$

${ }^{1}$ Cancer Epigenetics and Biology Programme (PEBC), Bellvitge Biomedical Research Institute (IDIBELL), 08908 L'Hospitalet de Llobregat, Barcelona, Spain.

${ }^{2}$ Human Genetics and Genomic Medicine, Faculty of Medicine University of Southampton, Southampton, UK.

${ }^{3}$ Institute of Human Genetics, Medical Faculty, RWTH Aachen University, Aachen, Germany.

${ }^{4}$ Department of Medical Genetics, University of Cambridge and NIHR Cambridge Biomedical Research Centre, Cambridge, UK.

${ }^{5}$ Department of Environmental, Biological and Pharmaceutical Sciences and Technologies, University of Campania "Luigi Vanvitelli", Caserta; Institute of Genetics and Biophysics "Adriano Buzzati-Traverso", CNR, Napoli, Italy.

*email: andrea.riccio@unicampania.it

\begin{abstract}
|
Genomic imprinting, the monoallelic and parent-of-origin-dependent expression of a subset of genes, is required for normal development. Its disruption leads to human disease involving isolated or multi-locus epigenetic changes that can be traced back to alterations of cis-acting sequences or trans-acting factors controlling the establishment, maintenance and erasure of germline epigenetic imprints or may have no evident genetic cause. Recent insights into the dynamics of the epigenome including the effect of environmental factors suggest that the developmental outcomes and heritability of imprinting disorders are influenced by interactions between the genome, the epigenome and the environment in germ cells and early embryos. In this Review, we discuss the latest advances in the study of genomic imprinting, focusing on the imprinting life-cycle and its possible errors leading to human diseases. We discuss the modes of inheritance of imprinting defects and
\end{abstract}


evidences from humans and animal models that environmental factors may influence genomic imprinting. Finally, we highlight areas requiring additional research that could complete our understanding of imprinting disorders, as well as new technological advances that might correct imprinting errors.

\section{Introduction}

In therian mammals, a subset of autosomal genes is preferentially expressed from only one of the two parental chromosomes, some from the maternally inherited allele, others from the paternal allele ${ }^{1}$. This parental origin-dependent expression results from differential epigenetic marking, primarily from methylated cytosine at CpG dinucleotides of genes during gametogenesis in the male and female germline. These genomic imprints endure for one generation, from their establishment in mature germ cells of an individual to their erasure in the gamete precursors of their progeny. Genomic imprinting thus represents a type of intergenerational epigenetic inheritance. Of note, parent-of-origin-dependent methylation differs from sequencedependent allelic methylation, in which stochastic fluctuation between epialleles [G] is influenced by genetic variants ${ }^{2}$.

In humans, approximately 100 imprinted genes have been identified ${ }^{3-5}$. Many imprinted genes have important roles during human development, and alteration of their expression and function can lead to imprinting disorders (Table 1), congenital conditions with a lifelong impact on health and in some cases increased cancer risk ${ }^{6}$. Molecular changes underlying imprinting disorders comprise genetic changes, such as copy number variants (CNVs), uniparental disomy [G] (UPD), and pathogenic gene sequence variants, or epigenetic changes that affect the regulation of imprinted loci (epimutations [G]). The frequency of the four types of molecular alterations varies markedly between different imprinting disorders, with the highest frequency of epimutations in the chromosome 11p15-associated disorders Beckwith-Wiedemann syndrome (BWS) and Silver-Russell syndrome (SRS) ${ }^{7}$. Epimutations that occur without detectable DNA sequence changes are referred to as primary epimutations and may represent random or environment-driven errors in the establishment or maintenance of an epigenetic programme. By contrast, secondary epimutations arise downstream from genetic changes that affect cis-acting elements or trans-acting 
factors $^{8}$. As normal imprinting marks once set persist throughout the life course of an organism, similarly, imprinting errors originating in the germline as primary or secondary epimutations are permanently maintained in somatic tissues, resulting in disease phenotypes later in development. Primary or secondary epimutations (as well as UPDs) that occur after fertilization can result in somatic mosaicism (Box 1). Although genetic alterations and epimutations differ in their nature and aetiology, they all disturb the fine-tuned balance of imprinted gene expression. In some cases, loss of methylation (LOM) and gain of methylation (GOM) of the same imprinting centre result in 'mirror' disorders that are broadly characterized by opposite clinical features and gene expression patterns, for example, in the case of BWS and SRS (Table 1 and Fig. 1$)^{7}$.

Advances in whole-genome sequencing and single-cell genome-wide analysis are driving the study of imprinting disorders arising from pathogenic variants that disrupt key epigenetic reprogramming processes in early embryogenesis, shedding new light on the dynamics of the epigenome as it passes from parents, through gametes, to offspring. Furthermore, recent studies on the interaction between environment and the epigenomes of gametes and early embryos suggest mechanistic explanations for the sporadic occurrence of imprinting errors.

This Review focuses on imprints that effect essentially permanent and ubiquitous (rather than tissue-specific or transient (Box 2)) changes on gene expression potential at affected loci. We begin with a brief overview of the genomic basis of imprinting and its control, before reviewing the lifecycle of genomic imprinting and how disruption of the individual factors involved in the establishment, maintenance and erasure of imprints can result in disease. Finally, we discuss the heritability of imprinting defects and the role of environmental insults in imprinting disorders. For details on the evolutionary significance of genomic imprinting ${ }^{1,9}$, the methods for imprinting analysis ${ }^{10}$, the physiological role of imprinted genes ${ }^{6}$ or the chromatin mechanisms in imprinting ${ }^{11}$, the reader is referred to previous authoritative reviews.

\section{[H1] The genomic basis of imprinting}

The majority of imprinted genes are found in clusters, called imprinted domains, which enables coordination via shared regulatory elements such as long non-coding RNAs (IncRNAs) and differentially methylated regions (DMRs), where DNA methylation differs between the maternally derived and paternally derived alleles. 
Each imprinted domain is controlled by an independent 'imprinting centre', which is generally characterized by a germline differentially methylated region (gDMR), also known as primary DMR (Fig. 2). About 35 gDMRs associated with imprinted loci have been identified in the human genome (Table 2$)^{12}$. gDMRs are also characterized by different chromatin configurations on parental chromosomes, with histone marks characteristic of closed chromatin (for example, histone 3 lysine 9 dimethylation (H3K9me2), trimethylation (H3K9me3) and histone 4 lysine 20 trimethylation (H4K20me3)) on the methylated allele, and histone marks characteristic of open chromatin (for example, H3K4me2 and H3K4me3) on the unmethylated allele (Fig. 2) ${ }^{4,11,13}$. The methylated and unmethylated gDMR alleles are recognized by different transcription factors whose function is to direct differential epigenetic modification and imprinted expression of the locus (Fig. 2$)^{14}$. Whereas maternally methylated gDMRs are more numerous, intragenic and generally correspond to promoters, often of IncRNAs, gDMRs methylated on the paternal chromosomes are intergenic and may function as insulators or enhancers (Table $2)^{1,15}$. Of note, in multigenic imprinted domains, the imprinting centre often directs the expression of genes from both the chromosome on which is methylated and the opposite parental chromosome; this situation arises from the regulatory interactions between imprinting centres and the gene products, both coding and noncoding, under their control (Fig. 2).

\section{[H2] Allele-specific expression in somatic cells}

Imprinted genes can display monoallelic expression in most or all cell types, but for some genes imprinted expression is restricted to specific tissues (for example, $U B E 3 A^{16,17}$ ) or developmental windows (for example, $K C N Q 1^{18}$ ), or monoallelic expression and/or methylation can differ between individuals ${ }^{19-21}$. To control the allele-specific expression of imprinted genes in somatic cells, gDMRs direct the establishment of further allele-specific epigenetic features within the imprinted domain during development. These include secondary DMRs (also known as somatic DMRs), which correspond mostly to gene promoters and transcription factor binding sites (Table 2$)^{20}$, chromatin modifications and higher-order chromatin structures (possibly resulting from CTCF-cohesin interactions) ${ }^{22,23}$, and IncRNAs with silencing capacity for flanking imprinted genes in $\operatorname{cis}^{24}$ (Figs 1, 2a) (reviewed in REF. ${ }^{1}$ ). In other cases, imprinted gDMRs direct alternative splicing, transcription 
elongation or polyadenylation site usage, which results in allele-specific transcript isoforms ${ }^{20,25}$. A minority of genes with parent of origin-dependent expression in somatic tissues have no evident DMR in their vicinity ${ }^{20}$, and their allele-specific expression may possibly be controlled by epigenetic features other than DNA methylation $^{26}$.

Tandem repeats are a prominent feature of imprinting centres ${ }^{27}$. Some repeats function to concentrate a high density of binding sites for transcription factors that regulate imprinted gene expression; for example, the tandem repeats in the $\mathrm{H} 19$ IGF2 IG-DMR concentrate methylation restricted binding of ZFP57 and CTCF that are critical for imprinting (Fig. 2) ${ }^{28,29}$. In this case, their recombination results in recurrent imprinting defects ${ }^{30}$. On the other hand, deletion of a large array of repeats of long-interspersed elements (LINE-1) in the DIk1-Dio3 imprinting domain in mouse embryonic stem (ES) cells did not disrupt imprinting, or, apparently normal development of both maternal and paternal mutant mice ${ }^{31}$, which does not support a role for these repeats in imprinting.

Imprinted gene products intensify their exquisite regulation by co-operation in a network (Imprinted gene network, IGN) ${ }^{32,33}$. For example, the transcription factor PLAGL1 $^{32}$ and the $H 19$ IncRNA ${ }^{33}$ have been shown to regulate the mRNA level of several members of the IGN in a DNA methylation-independent manner, in mouse tissues. The human IncRNA IPW, which resides within the Prader-Willi syndrome (PWS) locus on chromosome 15, is able to regulate the expression of MEG3 on chromosome 14 by targeting the EHMT2 H3K9 histone methyltransferase (also known as G9a) to its imprinting centre ${ }^{34}$. Furthermore, many imprinted gene clusters encode microRNAs (miRNAs) and small nucleolar RNAs (snoRNAs), which may be involved in the post-transcriptional control of imprinted genes ${ }^{35}$. These interactions may explain some of the overlaps observed in the phenotypes of imprinting disorders (Table 1).

\section{[H2] Multilocus imprinting disturbances}

A subset of patients with imprinting defects exhibits multilocus imprinting disturbances (MLID), that is, imprinting disruption at multiple loci across the genome. MLID is confined to epimutation subgroups of imprinting disorders (Table 1 ) and involves loci associated with known imprinting disorders as well as those not currently linked with specific phenotypes ${ }^{36,37}$. To date, most patients with MLID have 
shown clinical features characteristic of one imprinting disorder, notably BWS, SRS or transient neonatal diabetes mellitus (TNDM), which is probably due to the high frequency of epimutations in these imprinting disorders. However, epigenotypephenotype correlations are not always obvious, possibly because of the spectrum of epimutations involved or their mosaic nature $(\operatorname{Box} 1)^{37-39}$.

\section{[H1] The imprinting life-cycle and disease}

Throughout their generational lifespan (Fig. 3), genomic imprints must be maintained and preserved from epigenetic reprogramming in somatic cells. Many factors involved in these complex processes and their DNA binding sites can be targets of mutations that cause human imprinting disorders (Table 3).

\section{[H2] Imprinting centre methylation dynamics in germ cells}

Of the ubiquitous gDMRs present in somatic tissues, all but two originate from the oocyte (Table 2$)^{5,12}$. This disparity reflects fundamental differences in the mechanisms of methylation acquisition in the female and male germlines, and in the treatment of parent-of-origin-derived methylation in the zygote (Fig. 3$)^{21}$. In primordial germ cells (PGCs), the precursors of sperm and oocytes, germline specification requires remodelling of the epigenome as a pre-requisite for gametogenesis. Our knowledge of these processes comes chiefly from studies in mice ${ }^{40,41}$, and the characterization of human PGCs has revealed subtle interspecies differences, but overall the global erasure of methylation is comparable ${ }^{42-44}$.

A hallmark of PGC remodelling is imprint erasure. Genome-wide de-methylation of 5methylcytosine $(5 \mathrm{mC})$ is a passive process during PGC expansion that results from diminished protein levels of the de novo DNA methyltransferase DNMT3A and UHRF1, the recruitment factor of the maintenance DNA methyltransferase DNMT1. Reprogramming of imprinted methylation follows slower kinetics. In mice, it is associated with oxidation of $5 \mathrm{mC}$ to 5 -hydroxymethylcytosine $(5 \mathrm{hmC})$ by the teneleven translocation $5 \mathrm{mC}$ dioxygenase 1 (TET1) and TET2; this modification is not recognized by the maintenance methylation machinery and therefore promotes passive demethylation ${ }^{40,41,44,45}$.

Errors in the erasure process have been observed in patients with rare, sporadic imprinting disorders. In the case of GOM of the PWS/AS imprinting centre (also 
known as SNURF:TSS-DMR), grandmaternal methylation is not erased in paternal PGCs, and as a result the paternal allele retains this maternal imprint (Fig. 4a) ${ }^{46}$. Similarly, the hypermethylation of imprinting centres in sperm from subfertile individuals is consistent with incomplete erasure of imprints ${ }^{47}$.

Re-methylation and imprint acquisition occur asynchronously between the sexes, with de novo methylation in the male germline occurring before birth and maintained through many cycles of mitotic division before entry into meiosis, whilst female germ cells remain hypomethylated until maturation (Fig. 3). De novo methylation and imprint acquisition initiate in meiotically arrested (at prophase I) mouse oocytes following birth, and are largely completed by the germinal vesicle stage of development and resumption of meiosis ${ }^{42,48-51}$. Such dynamics have not been extensively studied in human oocytes ${ }^{52}$; however, in humans, meiosis II oocytes and the first and second polar bodies have comparable methylation, including at imprinted maternally methylated gDMRs ${ }^{49}$ (D. M., unpublished observations), which suggests the timings are similar to mouse.

On the basis of data derived from mouse models, the majority of methylation is deposited in oocytes by DNMT3A and its obligate, catalytically inert, cofactor DNMT3L ${ }^{51,53,54}$, whereas both DNMT3A and DNMT3B contribute in male germ cells $^{55}$. DNMT1 has an auxiliary role ensuring symmetric methylation of CpG sites in oocytes $^{56}$. Transcription and underlying chromatin signature are important factors determining methylation acquisition ${ }^{50}$. Transcription in oocytes is required for methylation at numerous $\mathrm{gDMRs}^{57}$, an act that may render the chromatin more accessible to the de novo methylation machinery and/or be associated with specific chromatin changes. The co-transcriptional histone H3K36me3 mark is deposited at intragenic $\mathrm{CpG}$ islands and subsequently recognized by DNMT3A and DNMT3B ${ }^{58,59}$. Successive removal of dimethylation and trimethylation of histone H3K4 by KDM1A or KDM1B (known previously as AOF1 and LSD1, respectively) allows for direct interaction with DNMT3L ${ }^{60-62}$. Despite being a generic methylase in mouse oocytes, DNMT3L is not detectable by expression profiling in human oocytes between germinal vesicle phase and meiosis $\mathrm{II}^{63}$, suggesting that it is not required for de novo methylation in the human female germline. In mouse male germ cells, transcriptional read-through is involved in acquisition of imprinting centre methylation, whereas histone H3K4 methylation and promoter activity are present at maternal imprinting centres that are protected from de novo methylation ${ }^{64}$. 
Failure to establish imprints during gametogenesis can result in imprinting disorders. Establishment of gDMRs involves several enzymatic steps, any of which may be prone to stochastic errors. In oocytes, deficient transcription through CpG islands destined to be gDMRs can result in failure to establish maternal imprints ${ }^{57}$; in such cases, there would be no mosaicism (Fig. 4b) ${ }^{65}$. Genetic mutations affecting transcription through the gDMR have been identified in rare patients with BWS with complete and isolated lack of methylation at the imprinting centre 2 (IC2), the imprinting centre of the centromeric domain of the BWS/SRS locus (also known as KCNQ1OT1:TSS-DMR) (REF ${ }^{66}$ and A. R., unpublished observations), and disruption of germline transcription is probably also present in Angelman Syndrome (AS) cases with non-mosaic LOM of the SNURF:TSS-DMR and deletions of the AS smallest region of deletion overlap (AS-SRO) ${ }^{67}$.

\section{[H2] Imprinting centre methylation dynamics in the early embryo}

The divergent DNA methylation patterns of oocyte and sperm are harmonized by the time the embryo reaches the blastocyst stage ${ }^{51,68}$, as part of the extensive epigenetic reprogramming that underpins zygotic genome activation [G] (ZGA; Box 3 and reviewed in $\mathrm{REF}^{69}$ ) and is required first to acquire totipotency and subsequently to initiate differentiation. The murine paternal genome is demethylated early in the first cell cycle, in part by TET3-induced oxidation of $5 \mathrm{mc}^{5,49,68,70}$, whereas maternal demethylation is predominantly passive, by replicative dilution during cleavage-stage divisions, possibly through the restricted activity or localization of DNMT1 and its accessory factors (Fig. 3) ${ }^{71,72}$. Studies in human systems are currently limited but indicate differences in abundance and roles of DNMTs in the oocyte and embryo ${ }^{63}$. However, in both humans and mice, whereas most gDMRs lose DNA methylation in pre-implantation stages ${ }^{49,51}$, imprinting centres evade the embryonic wave of epigenetic reprogramming, and studies in both mouse models and human patients with rare imprinting disorders suggest they do so through interaction with critical factors expressed in the oocyte and early embryo.

\section{[H2] Oocyte factors}

DPPA3 (also known as Stella or PGC7) is required for the maintenance of DNA methylation in the early mouse embryo and protects $5 \mathrm{mC}$ from conversion to $5 \mathrm{hmC}$ 
in the maternal pronucleus, by associating with chromatin marked by $\mathrm{H} 3 \mathrm{~K} 9 \mathrm{me} 2^{73}$. DPPA3 is a maternal-effect gene: concepti of maternal null mice rarely progress beyond the two-cell stage, and their genomes are severely demethylated ${ }^{74}$.

Maternal-effect variants in NLRP proteins and associated factors have been implicated in pregnancy outcomes including hydatidiform mole [G] and infertility, as well as monozygotic twinning, pregnancy loss and MLID (Fig. 4c-d $)^{37,39,75,76}$. Women with biallelic inactivating NLRP7 mutations are affected by familial hydatidiform mole $(\mathrm{FHM})^{77}$, where nonviable products of conception have normal biparental genomic constitution but complete loss of maternal imprinting marks. The high penetrance [G] of FHM suggests that NLRP7 is involved in oocyte-specific imprint establishment (Fig. 4C $)^{78}$, but hypomorphic maternal NLRP7 variants have been associated with $\mathrm{MLID}^{79}$.

In mouse models, NLRP5 and its associated proteins are referred to as the subcortical maternal complex $(\mathrm{SCMC})^{80}$. They are highly expressed in the oocyte, but their mRNA and protein abundance decline to undetectable levels by blastulation $^{81}$. In mouse models, maternal ablation of SCMC gene function compromises embryo development, with frequent demise between the 2-cell and blastula stage, and disruption of processes including maintenance of genome integrity, euploidy, mitochondrial function, and gene transcription and translation ${ }^{82-84}$. A mouse model of maternal NIrp2 deficiency shows severe reproductive compromise with embryo demise at all developmental stages and mosaic loss and gain of methylation at imprinted loci, indicating that abnormal subcellular localization of DNMT1 and or SCMC members may cause early embryonic loss and imprinting defects $^{85}$.

The effects of maternal SCMC variants suggest a link between DNA methylation, genome integrity and developmental competence in the early embryo. If the embryo's competence is severely compromised, both ploidy and DNA methylation may be intolerably affected, leading to embryo demise. If errors in ploidy and/or methylation are tolerated, the embryo may survive blastulation and continue development, with ongoing differentiation overwriting early epigenetic errors except for imprints, which are indelible in somatic cells. Evidence for this comes from reports of preimplantation genetic diagnosis of embryos with maternal-effect NLRP7 mutations in which all cleavage-stage embryos arrested and had various maternal aneuploidies $^{86}$. Arguably, if an embryo had presented with a normal chromosome 
complement it would have likely developed into a molar pregnancy or severe MLID due to disturbed maternal imprints. Hence, MLID may be no more or less than evidence of embryonic crises during the critical window encompassing epigenetic reprogramming and ZGA, with an ascertainment bias for live birth and normal ploidy. Mothers with maternal-effect variants have children with variable disturbance of both paternally- and maternally-methylated imprinting centres (Fig. 4d), and a spectrum of reproductive outcomes including apparent infertility, fetal loss, hydatidiform mole, liveborn children with MLID who exhibit clinical symptoms, and liveborn children with MLID and no clinical phenotypes ${ }^{37,39}$. The only consistent feature of offspring is MLID itself.

\section{[H2] Zygotic factors}

The KRAB zinc-finger protein (KRAB ZFP) ZFP57 acts as the focus for a multiprotein complex that protects imprinting centres from both passive and active demethylation ${ }^{87-89}$. ZFP57 recognizes a hexameric motif enriched in all maternally and paternally methylated imprinting centres in mouse ${ }^{90,91}$. KRAB ZFPs are a large, expanding family; their rapid evolution seems to keep pace with the endogenous retroviruses (ERVs) whose expression they suppress through DNA hypermethylation ${ }^{92}$. Besides repressing retroviral transcription, ZFP57 protects DNA methylation of imprinted loci in early development. In mice, Zfp57 is a maternalzygotic-effect gene the ablation of which is incompatible with full offspring survival ${ }^{87}$. Human ZFP57 acts zygotically, with recessive mutations associated with the imprinting disorders TNDM and a specific pattern of $\mathrm{MLID}^{93}$, although this may represent ascertainment bias of mutation patterns that are compatible with life (Fig. 4e). It is probable that additional KRAB ZFPs expressed in the oocyte, acting via maternal-effect, are involved in earlier imprinting centre maintenance in humans with a degree of redundancy between ZFPs in recruiting the KRAB repressor complex to specific gDMRs.

Human mutations have rarely been identified in other zygotic factors implicated in methylation maintenance, presumably because complete ablation would be incompatible with life, as seen in mouse models (for example, Trim28 ${ }^{94}$, Uhrf1 ${ }^{95}$ and Dnmt $1^{71}$ ). Nonetheless, haploinsufficiency of TRIM28/KAP1 has been associated with polyphenism, obesity and reduced expression of imprinted genes in mice and humans $^{96}$, and haploinsufficiencies of DNMT1 and UHRF1 have been described in 
association with BWS and MLID, respectively ${ }^{39,97}$. Cis-acting genetic variants have been identified in imprinting centre sequences, and study of these variants can help identify the zygotic factors that act on them to perpetuate the imprinted status (Fig. 4f-g). Inherited microdeletions in IC1 (which controls the imprinted expression of IGF2 and H19 at chromosome 11p15.5) mostly derived from recombination between repeats have been described in individuals with $\mathrm{BWS}^{30}$ and $\mathrm{SRS}^{98}$, but interestingly their effects are seen only in maternal and paternal inheritance, respectively, and the methylation defects are generally mosaic, once again suggesting that imprinted states acquired in the early embryo are faithfully perpetuated in subsequent development. In patients with SRS, no maternal transmissions have yet been reported, but it is suggested that loss of ZFP57 binding sites may result in postzygotic attrition of methylation (Fig. 4f ${ }^{29}$; in patients with BWS, erroneous GOM of the maternal allele is thought to result from loss of SOX2 and POU5F1 binding or weakening of CTCF binding ${ }^{28,99}$ (Fig. 4g). Murine models demonstrate that CTCF and ZFP57-binding sequences are involved in embryonic maintenance of IC1 imprinting $^{90,100}$, although some differences may exist between human and mouse species $^{101}$.

In summary, it seems that imprinting centre sequences have characteristics that support allele-specific gene expression, chromatin organization and DNA methylation in the early embryo, enabling these patterns to evade early-embryonic reprogramming and subsequently persist in somatic tissues.

\section{[H2] Intergenerational inheritance of imprinting defects}

Most imprinting disorders caused by epimutations occur in individuals with no relevant family history (primary epimutation). In such cases the underlying molecular cause may be associated with an environmental insult or stochastic error, and the risk of further cases in the family is minimal. Consistent with the hypothesis of nonheritability of primary epimutations, a methylation defect shown to have originated in an individual with SRS was subsequently abolished in his germline (Fig. 5a) ${ }^{102}$. However, a subset of isolated cases may have an underlying genetic cause even in the absence of a family history (secondary epimutation). Multiple genetic causes of secondary epimutations have been identified, providing important information on the cis-acting elements and trans-acting factors involved in imprinting control. Often, these cases are autosomal dominantly inherited, with parent-of-origin effects on 
penetrance, such that the epimutation and clinical phenotype only appear on maternal or paternal transmission (for example, familial PWS with paternallyinherited imprinting centre mutations (Fig. 5b) ${ }^{46}$, and familial BWS associated with maternally-inherited IC1 microdeletions (Fig. 5c) ${ }^{30}$ and POU5F1-binding sites variants ${ }^{99}$ ). However, autosomal recessively inherited TNDM is caused by pathogenic variants in ZFP57 (Fig. $5 \mathrm{~d})^{93}$, and maternal pathogenic variants in maternal-effect genes (NLRP2, NLRP5, NLRP7, PADI6 and OOEP) (Fig. 5e) ${ }^{39}$ are associated with MLID in offspring. In the case of maternal-effect variants, the recurrence risk after an affected pregnancy can be up to 100\% (recurrence may be avoided by oocyte donation), although even in the most severe forms penetrance may be incomplete (for example, NLRP7 familial hydatidiform moles) and there may be variable phenotypic expression ${ }^{37,39}$.

Genetic variants associated with imprinting centre epimutations can demonstrate variable clinical presentation and incomplete penetrance ${ }^{28}$ or apparent anticipation [G] with increased clinical severity over multiple generations ${ }^{103}$. These findings suggest that whereas highly-penetrant variants, such as those disrupting transcription factor binding, exhibit patent and penetrant phenotypes, genomic variants with lower penetrance may need to be identified by comprehensive sequencing efforts. Consistent with this hypothesis, a recent study demonstrated that frequent sequence variants have subtle effects on imprinted methylation, expression and phenotype ${ }^{20}$, suggesting that imprinting is a more quantitative than categorical phenomenon.

\section{[H1] Environmental influences on imprinting}

In addition to genetic causes of imprinting centre epimutations, environmental factors may also influence the imprinting process. In humans, evidence for this phenomenon derives from assisted reproductive technologies (ART) ${ }^{104}$. Other environmental influences on imprinting centres may include nutritional status or exposure to chemical pollutants in utero ${ }^{105}$. In many cases, changes in methylation represent increased variability on the methylated allele, likely relating to a failure of maintenance, or an adaptive response to the external stimuli.

\section{[H2] Assisted reproductive technologies}


ART is usually performed for male and/or female infertility and includes procedures such as ovarian hyperstimulation to obtain multiple oocytes for retrieval, in-vitro fertilization (IVF), intracytoplasmic sperm injection (ICSI) and embryo culture and transfer, all of which coincide with critical events in epigenome reprogramming. Reports of ART-conceived children with rare imprinting disorders (for example, AS and BWS) first suggested a potential link with the occurrence of epimutations at imprinting centres (Fig. 6) ${ }^{106-108}$. Epidemiological studies have provided further evidence for an increased risk of having children with BWS, AS or SRS when using $A R T^{104,109}$, although the absolute risk is very small (for example, for BWS up to 10fold increased risk compared to no ART, and $<0.1 \%$ of all children conceived with ART help) ${ }^{109}$. ART has also been associated with an increased frequency of MLID, but this has not been a universal finding ${ }^{110,111}$. MLID and Large Offspring syndrome (a condition with similarities with BWS) have been observed in bovine fetuses conceived by $\mathrm{IVF}^{112}$. In pigs, global genomic DNA methylation and/or gene expression, including imprinted loci and genes involved in epigenetic reprogramming, were altered in blastocysts produced by IVF and partially restored with addition of natural reproductive fluids ${ }^{113}$. Furthermore, superovulation and embryo transfer induced developmental defects and imprinting centre epimutations in the placenta of mouse models ${ }^{114}$.

In addition to ART-related procedures, infertility per se has been linked to the pathogenesis of imprinting disorders (Fig. 6). The frequency of AS with epimutations was shown to be increased in subfertile couples, independent of IVF, ICSI or embryo culture $^{115}$. More recently, impaired methylation of imprinting centres was reported in sperm of subfertile men ${ }^{47}$. Furthermore, unrecognized ART-associated epigenetic alterations may play a role in the increased risk of low birthweight and congenital anomalies that have been reported in ART-conceived children ${ }^{116}$ and animal models $^{117}$. Maternal age and delayed ovulation or fertilization are associated with depletion of oocyte proteins and RNA stores and altered developmental fitness of embryos $^{118-120}$, suggesting that maternal effect genes may be critically vulnerable to these or other challenges that occur during ART (Fig. 6).

Disentangling the effects of infertility and ART in the aetiology of ART-associated imprinting disorders in humans is difficult and not all studies have shown an association between ART and altered methylation, with some reports suggesting that there is no increase in mosaicism or methylation aberrations at imprinted 
gDMRs $^{121,122}$. Other groups have reported perturbed imprinting in pre-implantation embryos suitable for transfer ${ }^{123}$, suggesting that - similar to aneuploidy epigenetic mosaicism in early embryos may be a normal occurrence. The rarity of ART-associated imprinting disorders suggests that they may result from a combination of multiple interacting factors, including specific aspects of ART protocols, infertility, genetic susceptibility and stochastic effects (Fig. 6). Moreover, epidemiological surveys often have ascertainment bias for liveborn offspring with clinically blatant phenotypes associated with imprinting disorders, while the frequency of clinical pregnancy, though well-known to be limited in ART, is not considered. Potentially, individuals with imprinting disorders represent the subset of IVF outcomes with the least pervasive disturbance and the most recognizable clinical features, and a more definitive study will require consideration of nonviable products of conception at all stages, including both epigenome and genome integrity.

\section{[H2] Nutrition and metabolic disorders}

Certain developmental windows are especially vulnerable to abnormal nutritional states $^{124}$, including pre- and early post-implantation development and lineage segregation when epigenetic modifications are re-established. Recent studies have indicated that maternal metabolic disorders can have lasting effects on offspring through many pathways, which are beginning to be characterized (Fig. 6). Maternal dietary and genetic obesity have been shown to reduce Dppa3 expression in mouse oocytes; the resultant significant increase in $5 \mathrm{hmC}$ and concomitant reduction in $5 \mathrm{mC}$ in maternal pronuclei produces subsequent hypomethylation at several imprinted gDMRs ${ }^{125}$.

Nutritional status may also affect epigenetic profiles at imprinted loci in a variety of ways. It is possible that the availability of free methyl donors, such as Sadenosylmethionine, a substrate for DNA and protein methylation, is limited, with evidence that methyl-deficient diets, folate levels and genetic variants in proteins involved in one-carbon metabolism all affect imprinted methylation patterns, at the 11p15.5 imprinted gene cluster ${ }^{97,126,127}$. In these studies, the presence of missense amino acid substitutions in genes regulating the S-adenosyl methionine (SAM) or the inhibitory S-adenosylhomocyteine (SAH) abundance correlate with aberrant imprinted methylation ${ }^{126,127}$, which also revealed a link between low vitamin B12 levels and $H 19$ methylation maintenance ${ }^{126}$ Functional genetic variants of 
DNMT1 in BWS patients were also observed in combination with SNV of folate metabolism pathway genes, suggesting that decreased DNMT1 enzymatic activity could be exaggerated by extreme SAM/SAH ratios ${ }^{97}$. Furthermore, the ZFP57 locus is a folate-sensitive region, and its genomic binding regions are metastable epialleles responsive to periconceptional conditions ${ }^{128,129}$. In mouse, withdrawal of maternal dietary protein permanently altered imprinted expression of Cdkn1c in offspring, which was maintained into adulthood and occurred through a folate-dependent mechanism of DNA methylation loss ${ }^{130}$. However, not all studies on isocaloric protein restriction during pregnancy have resulted in altered imprinted methylation in the newborn ${ }^{131}$, suggesting that any deregulation is likely a consequence of a general effect on global methylation. Recent evidence suggests that cells have important energy status sensors that protect the cells against metabolic stress by directly regulating epigenetic processes. The nicotinamide adenine dinucleotide (NAD)dependent deacetylase, SIRT1 has been shown to protect methylation at imprinted loci by directly regulating acetylation of DNMT3L, at both the promoter and protein level in mouse embryonic stem cells ${ }^{132}$.

\section{Endocrine disruptors}

In addition to micronutrient availability, prenatal exposure to estrogenic endocrinedisrupting compounds (EDC), such as bisphenol A (BPA), results in deregulation of genomic methylation and hydroxymethylation ${ }^{133,134}$, with imprinting and methylation anomalies being reported in both mouse placenta ${ }^{135}$ and developing gametes ${ }^{136,137}$. Endorsing the vulnerability of imprinted loci to EDCs, prenatal BPA exposure in humans has been associated with changes in methylation at the MEST locus and is linked with early childhood obesity ${ }^{138}$. Dnmt1 expression was found to be decreased in BPA-treated mouse spermatogonia ${ }^{137}$, and BPA exposure during oocyte maturation altered other epigenetic marks, specifically the abundance of histone modifications, which was linked to induced oxidative stress ${ }^{139}$. Exposure-induced oxidative stress was shown to alter both TET enzyme expression and function, leading to altered 5 -hmC levels at numerous imprinted loci $^{134}$, which indicates that environmental toxicants also alter long-term imprinted gene regulation (Fig. 6). Indirect effects of the toxic compounds on DNA methylation could also be exerted as consequence of developmental and metabolic alterations ${ }^{140}$. 
In summary, combined genetic and environmental predispositions may erode the gametic and zygotic competence to reprogramme the epigenome, with consequences on imprint maintenance, and insights into these effects in humans may be gained by delineating the aetiology of apparently sporadic primary epimutations in individuals with imprinting disorders.

\section{[H1] Conclusions and perspectives}

The maintenance of differential DNA methylation of imprinting centres is fundamental for the survival of imprinting marks in the early embryo. Some of the key factors and genomic sequences involved in this process have been identified, but the causation and timing of their interactions require further clarification. This is particularly true for the SCMC proteins and possibly further oocyte-specific factors that affect DNA methylation maintenance in the early embryo, whose mechanisms of action and relationship with ZGA are still ill-defined. Importantly, further human-based studies are required, firstly to resolve key differences from mouse in the timing and mechanisms of epigenetic remodelling, and secondly to learn from rare cases of imprinting disorders by identifying genetic variants that predispose to imprinting centre epimutations.

It has also become evident that environmental changes can affect the epigenetic reprogramming of germ cells and early embryo, altering their developmental competence and causing imprinting disorders. The availability or activity of factors needed for imprint establishment or maintenance may be affected by exposure to chemical pollutants, under- or over-nourishment, or other emergent factors. Omic and functional analyses of early embryos and nonviable reproductive outcomes will clarify the relationship between epigenomic and genomic integrity, uncover the key processes involved, and enable the creation of model systems in which primary imprinting centre epimutations can be created and explored.

Cellular-physiological approaches are beginning to uncover key interactions of imprinted gene products, their effects on growth and metabolism, and their disturbance in imprinting disorders ${ }^{32-34,101}$. Such approaches, and their extension into human pathophysiology, will shed further light on molecular mechanisms of disease, (epi)genotype-phenotype correlations, phenotypic modification by mosaicism and MLID, and potential therapies for some of the resultant endocrine and growth disturbances. 
More fundamentally, there are possibilities for therapeutic correction of imprinting disorders based on the reversal of gene imprinting status. Three therapeutic approaches for the neurological disorders AS and PWS have been proposed ${ }^{141-143}$. The AS/PWS locus contains a maternally methylated imprinting centre that directs the paternal expression of several genes, including a snoRNA cluster with a critical role in PWS and an antisense regulator (UBE3A-ATS) of the maternally-expressed E3 ubiquitin ligase $U B E 3 A$, the expression of which is lost in AS (Table 1). It was demonstrated that a topoisomerase inhibitor ${ }^{143}$ as well as antisense oligonucleotides $^{141}$ are able to downregulate UBE3A-ATS and reactivate the paternal UBE3A in mouse models of AS, whereas G9a inhibitors can unsilence the maternal snoRNAs in a PWS model ${ }^{142}$. Another exciting approach is the direct modification of epigenetic marks at imprinted genes using catalytically inactivated Cas9 (dCas9) fusion proteins. Although still in their infancy, dCas9-DNA methyltransferase fusions have been able to target methylation to IC1 in mouse cells ${ }^{144}$, a promising technology if such alterations can be performed in an allelic fashion. Future experiments will demonstrate whether these approaches with small molecules may revert other epimutations in imprinting disorders and possibly be applied in other epigenetic-based human diseases.

\section{References}

1 Barlow, D. P. \& Bartolomei, M. S. Genomic imprinting in mammals. Cold Spring Harb Perspect Biol 6, doi:10.1101/cshperspect.a018382 (2014).

2 Onuchic, V. et al. Allele-specific epigenome maps reveal sequence-dependent stochastic switching at regulatory loci. Science 361, doi:10.1126/science.aar3146 (2018).

3 Baran, Y. et al. The landscape of genomic imprinting across diverse adult human tissues. Genome Res 25, 927-936, doi:10.1101/gr.192278.115 (2015).

4 Court, F. et al. Genome-wide parent-of-origin DNA methylation analysis reveals the intricacies of human imprinting and suggests a germline methylation-independent mechanism of establishment. Genome Res 24, 554-569, doi:10.1101/gr.164913.113 (2014).

Full description of allelic DMRs in humans and first report of tissue-specific ICs.

5 Smith, Z. D. et al. DNA methylation dynamics of the human preimplantation embryo. Nature 511, 611615, doi:10.1038/nature13581 (2014).

Describes methylation landscape in human gametes and pre-implantation embryos.

$6 \quad$ Peters, J. The role of genomic imprinting in biology and disease: an expanding view. Nat Rev Genet 15, 517-530, doi:10.1038/nrg3766 (2014).

7 Eggermann, T. et al. Imprinting disorders: a group of congenital disorders with overlapping patterns of molecular changes affecting imprinted loci. Clin Epigenetics 7, 123, doi:10.1186/s13148-015-0143-8 (2015).

8 Horsthemke, B. Mechanisms of imprint dysregulation. Am J Med Genet C Semin Med Genet 154C, 321-328, doi:10.1002/ajmg.c.30269 (2010).

$9 \quad$ Haig, D. Colloquium papers: Transfers and transitions: parent-offspring conflict, genomic imprinting, and the evolution of human life history. Proc Natl Acad Sci U S A 107 Suppl 1, 1731-1735, doi:10.1073/pnas.0904111106 (2010). 
10 Eggermann, K. et al. EMQN best practice guidelines for the molecular genetic testing and reporting of chromosome 11p15 imprinting disorders: Silver-Russell and Beckwith-Wiedemann syndrome. Eur J Hum Genet 24, 1377-1387, doi:10.1038/ejhg.2016.45 (2016).

11 Sanli, I. \& Feil, R. Chromatin mechanisms in the developmental control of imprinted gene expression. Int J Biochem Cell Biol 67, 139-147, doi:10.1016/j.biocel.2015.04.004 (2015).

12 Monk, D. et al. Recommendations for a nomenclature system for reporting methylation aberrations in imprinted domains. Epigenetics 13, 117-121, doi:10.1080/15592294.2016.1264561 (2018).

13 Singh, P. et al. Chromosome-wide analysis of parental allele-specific chromatin and DNA methylation. Mol Cell Biol 31, 1757-1770, doi:10.1128/MCB.00961-10 (2011).

14 Riso, V. et al. ZFP57 maintains the parent-of-origin-specific expression of the imprinted genes and differentially affects non-imprinted targets in mouse embryonic stem cells. Nucleic Acids Res 44, 8165-8178, doi:10.1093/nar/gkw505 (2016).

15 Kota, S. K. et al. ICR noncoding RNA expression controls imprinting and DNA replication at the Dlk1-Dio3 domain. Dev Cell 31, 19-33, doi:10.1016/j.devcel.2014.08.009 (2014).

16 Rougeulle, C., Glatt, H. \& Lalande, M. The Angelman syndrome candidate gene, UBE3A/E6-AP, is imprinted in brain. Nat Genet 17, 14-15, doi:10.1038/ng0997-14 (1997).

$17 \mathrm{Vu}, \mathrm{T}$. H. \& Hoffman, A. R. Imprinting of the Angelman syndrome gene, UBE3A, is restricted to brain. Nat Genet 17, 12-13, doi:10.1038/ng0997-12 (1997).

18 Travers, M. E. et al. Insights into the molecular mechanism for type 2 diabetes susceptibility at the KCNQ1 locus from temporal changes in imprinting status in human islets. Diabetes 62, 987-992, doi:10.2337/db12-0819 (2013).

19 Hanna, C. W. et al. Pervasive polymorphic imprinted methylation in the human placenta. Genome Res 26, 756-767, doi:10.1101/gr.196139.115 (2016).

20 Zink, F. et al. Insights into imprinting from parent-of-origin phased methylomes and transcriptomes. Nat Genet 50, 1542-1552, doi:10.1038/s41588-018-0232-7 (2018).

Description of partial phenotypes associated with parent-of-origin-specific genotypes that influence imprinted gene expression.

21 Sanchez-Delgado, M. et al. Human Oocyte-Derived Methylation Differences Persist in the Placenta Revealing Widespread Transient Imprinting. PLoS Genet 12, e1006427, doi:10.1371/journal.pgen.1006427 (2016).

Demonstrates oocyte-derived methylation and polymorphic transient-DMRs.

22 Tan, L., Xing, D., Chang, C. H., Li, H. \& Xie, X. S. Three-dimensional genome structures of single diploid human cells. Science 361, 924-928, doi:10.1126/science.aat5641 (2018).

Identifies allelic contacts and novel CTCF-mediated loops at the H19-Igf2 locus by single cell Hi-C profiling.

23 Rao, S. S. et al. A 3D map of the human genome at kilobase resolution reveals principles of chromatin looping. Cell 159, 1665-1680, doi:10.1016/j.cell.2014.11.021 (2014).

24 Kanduri, C. Long noncoding RNAs: Lessons from genomic imprinting. Biochim Biophys Acta 1859, 102-111, doi:10.1016/j.bbagrm.2015.05.006 (2016).

25 Niemczyk, M. et al. Imprinted chromatin around DIRAS3 regulates alternative splicing of GNG12AS1, a long noncoding RNA. Am J Hum Genet 93, 224-235, doi:10.1016/j.ajhg.2013.06.010 (2013).

26 Inoue, A., Jiang, L., Lu, F., Suzuki, T. \& Zhang, Y. Maternal H3K27me3 controls DNA methylationindependent imprinting. Nature 547, 419-424, doi:10.1038/nature23262 (2017).

Demonstrates that maternal H3K27me3 controls DNA methylation-independent imprinting in early mouse embryos independent of DMRs.

27 Hutter, B., Helms, V. \& Paulsen, M. Tandem repeats in the CpG islands of imprinted genes. Genomics 88, 323-332, doi:10.1016/j.ygeno.2006.03.019 (2006).

28 Beygo, J. et al. The molecular function and clinical phenotype of partial deletions of the IGF2/H19 imprinting control region depends on the spatial arrangement of the remaining CTCF-binding sites. $\mathrm{Hum} \mathrm{Mol}$ Genet 22, 544-557, doi:10.1093/hmg/dds465 (2013).

29 Sparago, A., Cerrato, F. \& Riccio, A. Is ZFP57 binding to H19/IGF2:IG-DMR affected in SilverRussell syndrome? Clin Epigenetics 10, 23, doi:10.1186/s13148-018-0454-7 (2018).

30 De Crescenzo, A. et al. A novel microdeletion in the IGF2/H19 imprinting centre region defines a recurrent mutation mechanism in familial Beckwith-Wiedemann syndrome. Eur J Med Genet 54, e451-454, doi:10.1016/j.ejmg.2011.04.009 (2011).

31 Soares, M. L. et al. Targeted deletion of a 170-kb cluster of LINE-1 repeats and implications for regional control. Genome Res, doi:10.1101/gr.221366.117 (2018).

32 Varrault, A. et al. Zac1 regulates an imprinted gene network critically involved in the control of embryonic growth. Dev Cell 11, 711-722, doi:10.1016/j.devcel.2006.09.003 (2006). 
33 Gabory, A. et al. H19 acts as a trans regulator of the imprinted gene network controlling growth in mice. Development 136, 3413-3421, doi:10.1242/dev.036061 (2009).

34 Stelzer, Y., Sagi, I., Yanuka, O., Eiges, R. \& Benvenisty, N. The noncoding RNA IPW regulates the imprinted DLK1-DIO3 locus in an induced pluripotent stem cell model of Prader-Willi syndrome. Nat Genet 46, 551-557, doi:10.1038/ng.2968 (2014).

35 Girardot, M., Cavaille, J. \& Feil, R. Small regulatory RNAs controlled by genomic imprinting and their contribution to human disease. Epigenetics 7, 1341-1348, doi:10.4161/epi.22884 (2012).

36 Court, F. et al. Genome-wide allelic methylation analysis reveals disease-specific susceptibility to multiple methylation defects in imprinting syndromes. Hum Mutat 34, 595-602, doi:10.1002/humu.22276 (2013).

37 Docherty, L. E. et al. Mutations in NLRP5 are associated with reproductive wastage and multilocus imprinting disorders in humans. Nat Commun 6, 8086, doi:10.1038/ncomms9086 (2015).

Identifies NLRP5 mutations in MLID.

38 Azzi, S. et al. A prospective study validating a clinical scoring system and demonstrating phenotypicalgenotypical correlations in Silver-Russell syndrome. J Med Genet 52, 446-453, doi:10.1136/jmedgenet-2014102979 (2015).

39 Begemann, M. et al. Maternal variants in NLRP and other maternal effect proteins are associated with multilocus imprinting disturbance in offspring. J Med Genet 55, 497-504, doi:10.1136/jmedgenet-2017-105190 (2018).

Identifies deleterious variants in maternal effect genes associated with the SCMC in MLID patients.

40 Hackett, J. A. et al. Germline DNA demethylation dynamics and imprint erasure through 5hydroxymethylcytosine. Science 339, 448-452, doi:10.1126/science.1229277 (2013).

Demonstrates that erasure of CpG methylation in mouse PGCs occurs via conversion to 5hydroxymethylcytosine (5hmC), driven by high levels of TET1 and TET2.

41 Seisenberger, S. et al. The dynamics of genome-wide DNA methylation reprogramming in mouse primordial germ cells. Mol Cell 48, 849-862, doi:10.1016/j.molcel.2012.11.001 (2012).

42 Guo, F. et al. The Transcriptome and DNA Methylome Landscapes of Human Primordial Germ Cells. Cell 161, 1437-1452, doi:10.1016/j.cell.2015.05.015 (2015).

First genome-wide description of the Transcriptome and DNA Methylome Landscapes of Human Primordial Germ Cells.

43 Tang, W. W. et al. A Unique Gene Regulatory Network Resets the Human Germline Epigenome for Development. Cell 161, 1453-1467, doi:10.1016/j.cell.2015.04.053 (2015).

44 Gkountela, S. et al. DNA Demethylation Dynamics in the Human Prenatal Germline. Cell 161, 14251436, doi:10.1016/j.cell.2015.05.012 (2015).

45 Dawlaty, M. M. et al. Combined deficiency of Tet1 and Tet2 causes epigenetic abnormalities but is compatible with postnatal development. Dev Cell 24, 310-323, doi:10.1016/j.devcel.2012.12.015 (2013).

$46 \quad$ Buiting, K. et al. Epimutations in Prader-Willi and Angelman syndromes: a molecular study of 136 patients with an imprinting defect. Am J Hum Genet 72, 571-577, doi:10.1086/367926 (2003).

47 Poplinski, A., Tuttelmann, F., Kanber, D., Horsthemke, B. \& Gromoll, J. Idiopathic male infertility is strongly associated with aberrant methylation of MEST and IGF2/H19 ICR1. Int J Androl 33, 642-649, doi:10.1111/j.1365-2605.2009.01000.x (2010).

48 Hiura, H., Obata, Y., Komiyama, J., Shirai, M. \& Kono, T. Oocyte growth-dependent progression of maternal imprinting in mice. Genes Cells 11, 353-361, doi:10.1111/j.1365-2443.2006.00943.x (2006).

49 Guo, H. et al. The DNA methylation landscape of human early embryos. Nature 511, 606-610, doi:10.1038/nature13544 (2014).

50 Gahurova, L. et al. Transcription and chromatin determinants of de novo DNA methylation timing in oocytes. Epigenetics Chromatin 10, 25, doi:10.1186/s13072-017-0133-5 (2017).

51 Smallwood, S. A. et al. Dynamic CpG island methylation landscape in oocytes and preimplantation embryos. Nat Genet 43, 811-814, doi:10.1038/ng.864 (2011).

52 Yu, B. et al. Genome-wide, Single-Cell DNA Methylomics Reveals Increased Non-CpG Methylation during Human Oocyte Maturation. Stem Cell Reports 9, 397-407, doi:10.1016/j.stemcr.2017.05.026 (2017).

53 Bourc'his, D., Xu, G. L., Lin, C. S., Bollman, B. \& Bestor, T. H. Dnmt3L and the establishment of maternal genomic imprints. Science 294, 2536-2539, doi:10.1126/science.1065848 (2001).

54 Kaneda, M. et al. Essential role for de novo DNA methyltransferase Dnmt3a in paternal and maternal imprinting. Nature 429, 900-903, doi:10.1038/nature02633 (2004).

$55 \quad$ Kato, Y. et al. Role of the Dnmt3 family in de novo methylation of imprinted and repetitive sequences during male germ cell development in the mouse. Hum Mol Genet 16, 2272-2280, doi:10.1093/hmg/ddm179 (2007). 
56 Shirane, K. et al. Mouse oocyte methylomes at base resolution reveal genome-wide accumulation of non-CpG methylation and role of DNA methyltransferases. PLoS Genet 9, e1003439, doi:10.1371/journal.pgen.1003439 (2013).

57 Chotalia, M. et al. Transcription is required for establishment of germline methylation marks at imprinted genes. Genes Dev 23, 105-117, doi:10.1101/gad.495809 (2009).

58 Baubec, T. et al. Genomic profiling of DNA methyltransferases reveals a role for DNMT3B in genic methylation. Nature 520, 243-247, doi:10.1038/nature14176 (2015).

Demonstrates the targeting of DNA methylation to transcribed gene bodies by SETD2-mediated methylation of H3K36me3 and a functional recruitment of DNMT3B.

59 Dhayalan, A. et al. The Dnmt3a PWWP domain reads histone 3 lysine 36 trimethylation and guides DNA methylation. J Biol Chem 285, 26114-26120, doi:10.1074/jbc.M109.089433 (2010).

60 Ciccone, D. N. et al. KDM1B is a histone H3K4 demethylase required to establish maternal genomic imprints. Nature 461, 415-418, doi:10.1038/nature08315 (2009).

61 Ooi, S. K. et al. DNMT3L connects unmethylated lysine 4 of histone H3 to de novo methylation of DNA. Nature 448, 714-717, doi:10.1038/nature05987 (2007).

62 Stewart, K. R. et al. Dynamic changes in histone modifications precede de novo DNA methylation in oocytes. Genes Dev 29, 2449-2462, doi:10.1101/gad.271353.115 (2015).

63 Petrussa, L., Van de Velde, H. \& De Rycke, M. Dynamic regulation of DNA methyltransferases in human oocytes and preimplantation embryos after assisted reproductive technologies. Mol Hum Reprod 20, 861874, doi:10.1093/molehr/gau049 (2014).

64 Henckel, A., Chebli, K., Kota, S. K., Arnaud, P. \& Feil, R. Transcription and histone methylation changes correlate with imprint acquisition in male germ cells. EMBO $J$ 31, 606-615, doi:10.1038/emboj.2011.425 (2012).

65 Singh, V. B. et al. Blocked transcription through KvDMR1 results in absence of methylation and gene silencing resembling Beckwith-Wiedemann syndrome. Development 144, 1820-1830, doi:10.1242/dev.145136 (2017).

66 Beygo, J. et al. A maternal deletion upstream of the imprint control region 2 in 11p15 causes loss of methylation and familial Beckwith-Wiedemann syndrome. Eur J Hum Genet 24, 1280-1286, doi:10.1038/ejhg.2016.3 (2016).

67 Lewis, M. W. et al. Angelman syndrome imprinting center encodes a transcriptional promoter. Proc Natl Acad Sci U S A 112, 6871-6875, doi:10.1073/pnas.1411261111 (2015).

68 Smith, Z. D. et al. A unique regulatory phase of DNA methylation in the early mammalian embryo. Nature 484, 339-344, doi:10.1038/nature10960 (2012).

69 Eckersley-Maslin, M. A., Alda-Catalinas, C. \& Reik, W. Dynamics of the epigenetic landscape during the maternal-to-zygotic transition. Nat Rev Mol Cell Biol 19, 436-450, doi:10.1038/s41580-018-0008-z (2018).

70 Shen, L. et al. Tet3 and DNA replication mediate demethylation of both the maternal and paternal genomes in mouse zygotes. Cell Stem Cell 15, 459-471, doi:10.1016/j.stem.2014.09.002 (2014).

$71 \quad$ Hirasawa, R. et al. Maternal and zygotic Dnmt1 are necessary and sufficient for the maintenance of DNA methylation imprints during preimplantation development. Genes Dev 22, 1607-1616, doi:10.1101/gad.1667008 (2008).

72 Maenohara, S. et al. Role of UHRF1 in de novo DNA methylation in oocytes and maintenance methylation in preimplantation embryos. PLoS Genet 13, e1007042, doi:10.1371/journal.pgen.1007042 (2017).

73 Nakamura, T. et al. PGC7 binds histone H3K9me2 to protect against conversion of 5mC to 5hmC in early embryos. Nature 486, 415-419, doi:10.1038/nature11093 (2012).

$74 \quad$ Nakamura, T. et al. PGC7/Stella protects against DNA demethylation in early embryogenesis. Nat Cell Biol 9, 64-71, doi:10.1038/ncb1519 (2007).

75 Meyer, E. et al. Germline mutation in NLRP2 (NALP2) in a familial imprinting disorder (BeckwithWiedemann Syndrome). PLoS Genet 5, e1000423, doi:10.1371/journal.pgen.1000423 (2009).

76 Parry, D. A. et al. Mutations causing familial biparental hydatidiform mole implicate c6orf221 as a possible regulator of genomic imprinting in the human oocyte. Am J Hum Genet 89, 451-458, doi:10.1016/j.ajhg.2011.08.002 (2011).

77 Murdoch, S. et al. Mutations in NALP7 cause recurrent hydatidiform moles and reproductive wastage in humans. Nat Genet 38, 300-302, doi:10.1038/ng1740 (2006).

78 Sanchez-Delgado, M. et al. Absence of Maternal Methylation in Biparental Hydatidiform Moles from Women with NLRP7 Maternal-Effect Mutations Reveals Widespread Placenta-Specific Imprinting. PLoS Genet 11, e1005644, doi:10.1371/journal.pgen.1005644 (2015).

79 Soellner, L. et al. Maternal heterozygous NLRP7 variant results in recurrent reproductive failure and imprinting disturbances in the offspring. Eur J Hum Genet 25, 924-929, doi:10.1038/ejhg.2017.94 (2017).

80 Zhu, K. et al. Identification of a human subcortical maternal complex. Mol Hum Reprod 21, 320-329, doi:10.1093/molehr/gau116 (2015). 
81 Virant-Klun, I., Leicht, S., Hughes, C. \& Krijgsveld, J. Identification of Maturation-Specific Proteins by Single-Cell Proteomics of Human Oocytes. Mol Cell Proteomics 15, 2616-2627, doi:10.1074/mcp.M115.056887 (2016).

82 Tong, Z. B. et al. Mater, a maternal effect gene required for early embryonic development in mice. Nat Genet 26, 267-268, doi:10.1038/81547 (2000).

83 Yurttas, P. et al. Role for PADI6 and the cytoplasmic lattices in ribosomal storage in oocytes and translational control in the early mouse embryo. Development 135, 2627-2636, doi:10.1242/dev.016329 (2008).

84 Zheng, P. \& Dean, J. Role of Filia, a maternal effect gene, in maintaining euploidy during cleavagestage mouse embryogenesis. Proc Natl Acad Sci U S A 106, 7473-7478, doi:10.1073/pnas.0900519106 (2009).

85 Mahadevan, S. et al. Maternally expressed NLRP2 links the subcortical maternal complex (SCMC) to fertility, embryogenesis and epigenetic reprogramming. Sci Rep 7, 44667, doi:10.1038/srep44667 (2017).

Generation of maternal-effect mouse model for Nlrp2 which revealed disrupted imprinted methylation consistent with human MLID.

86 Sills, E. S. et al. Pathogenic variant in NLRP7 (19q13.42) associated with recurrent gestational trophoblastic disease: Data from early embryo development observed during in vitro fertilization. Clin Exp Reprod Med 44, 40-46, doi:10.5653/cerm.2017.44.1.40 (2017).

$87 \mathrm{Li}$, X. et al. A maternal-zygotic effect gene, Zfp57, maintains both maternal and paternal imprints. Dev Cell 15, 547-557, doi:10.1016/j.devcel.2008.08.014 (2008).

88 Quenneville, S. et al. In embryonic stem cells, ZFP57/KAP1 recognize a methylated hexanucleotide to affect chromatin and DNA methylation of imprinting control regions. Mol Cell 44, 361-372, doi:10.1016/j.molcel.2011.08.032 (2011).

89 Coluccio, A. et al. Individual retrotransposon integrants are differentially controlled by KZFP/KAP1dependent histone methylation, DNA methylation and TET-mediated hydroxymethylation in naive embryonic stem cells. Epigenetics Chromatin 11, 7, doi:10.1186/s13072-018-0177-1 (2018).

90 Anvar, Z. et al. ZFP57 recognizes multiple and closely spaced sequence motif variants to maintain repressive epigenetic marks in mouse embryonic stem cells. Nucleic Acids Res 44, 1118-1132, doi:10.1093/nar/gkv1059 (2016).

91 Strogantsev, R. et al. Allele-specific binding of ZFP57 in the epigenetic regulation of imprinted and non-imprinted monoallelic expression. Genome Biol 16, 112, doi:10.1186/s13059-015-0672-7 (2015).

92 Imbeault, M., Helleboid, P. Y. \& Trono, D. KRAB zinc-finger proteins contribute to the evolution of gene regulatory networks. Nature 543, 550-554, doi:10.1038/nature21683 (2017).

Identifies human genome targets for 350 Krüppel-associated box (KRAB) domain-containing zinc-finger proteins

93 Mackay, D. J. et al. Hypomethylation of multiple imprinted loci in individuals with transient neonatal diabetes is associated with mutations in ZFP57. Nat Genet 40, 949-951, doi:10.1038/ng.187 (2008).

94 Messerschmidt, D. M. et al. Trim28 is required for epigenetic stability during mouse oocyte to embryo transition. Science 335, 1499-1502, doi:10.1126/science.1216154 (2012).

95 Sharif, J. et al. The SRA protein Np95 mediates epigenetic inheritance by recruiting Dnmt1 to methylated DNA. Nature 450, 908-912, doi:10.1038/nature06397 (2007).

96 Dalgaard, K. et al. Trim28 Haploinsufficiency Triggers Bi-stable Epigenetic Obesity. Cell 164, 353364, doi:10.1016/j.cell.2015.12.025 (2016).

97 Dagar, V. et al. Genetic variation affecting DNA methylation and the human imprinting disorder, Beckwith-Wiedemann syndrome. Clin Epigenetics 10, 114, doi:10.1186/s13148-018-0546-4 (2018).

98 Abi Habib, W. et al. 11p15 ICR1 Partial Deletions Associated with IGF2/H19 DMR Hypomethylation and Silver-Russell Syndrome. Hum Mutat 38, 105-111, doi:10.1002/humu.23131 (2017).

99 Demars, J. et al. Analysis of the IGF2/H19 imprinting control region uncovers new genetic defects, including mutations of OCT-binding sequences, in patients with 11p15 fetal growth disorders. Hum Mol Genet 19, 803-814, doi:10.1093/hmg/ddp549 (2010).

100 Freschi, A. et al. Tissue-specific and mosaic imprinting defects underlie opposite congenital growth disorders in mice. PLoS Genet 14, e1007243, doi:10.1371/journal.pgen.1007243 (2018).

101 Hur, S. K. et al. Humanized H19/Igf2 locus reveals diverged imprinting mechanism between mouse and human and reflects Silver-Russell syndrome phenotypes. Proc Natl Acad Sci U S A 113, 10938-10943, doi:10.1073/pnas.1603066113 (2016).

102 Bruno, C. et al. Germline correction of an epimutation related to Silver-Russell syndrome. Hum Mol Genet 24, 3314-3321, doi:10.1093/hmg/ddv079 (2015).

103 Berland, S. et al. Evidence for anticipation in Beckwith-Wiedemann syndrome. Eur J Hum Genet 21, 1344-1348, doi:10.1038/ejhg.2013.71 (2013).

104 Cortessis, V. K. et al. Comprehensive meta-analysis reveals association between multiple imprinting disorders and conception by assisted reproductive technology. J Assist Reprod Genet 35, 943-952, doi:10.1007/s10815-018-1173-x (2018). 
Meta-analysis demonstrating association between imprinting disorders and ART

105 Taniguchi, K., Kawai, T. \& Hata, K. Placental Development and Nutritional Environment. Adv Exp Med Biol 1012, 63-73, doi:10.1007/978-981-10-5526-3_7 (2018).

106 Cox, G. F. et al. Intracytoplasmic sperm injection may increase the risk of imprinting defects. Am $J$ Hum Genet 71, 162-164, doi:10.1086/341096 (2002).

107 DeBaun, M. R., Niemitz, E. L. \& Feinberg, A. P. Association of in vitro fertilization with BeckwithWiedemann syndrome and epigenetic alterations of LIT1 and H19. Am J Hum Genet 72, 156-160, doi:10.1086/346031 (2003).

108 Maher, E. R. et al. Beckwith-Wiedemann syndrome and assisted reproduction technology (ART). J Med Genet 40, 62-64 (2003).

109 Mussa, A. et al. Assisted Reproductive Techniques and Risk of Beckwith-Wiedemann Syndrome. Pediatrics 140, doi:10.1542/peds.2016-4311 (2017).

110 Tee, L. et al. Epimutation profiling in Beckwith-Wiedemann syndrome: relationship with assisted reproductive technology. Clin Epigenetics 5, 23, doi:10.1186/1868-7083-5-23 (2013).

111 Tenorio, J. et al. Clinical and molecular analyses of Beckwith-Wiedemann syndrome: Comparison between spontaneous conception and assisted reproduction techniques. Am J Med Genet A 170, 2740-2749, doi:10.1002/ajmg.a.37852 (2016).

112 Chen, Z. et al. Characterization of global loss of imprinting in fetal overgrowth syndrome induced by assisted reproduction. Proc Natl Acad Sci U S A 112, 4618-4623, doi:10.1073/pnas.1422088112 (2015).

113 Canovas, S. et al. DNA methylation and gene expression changes derived from assisted reproductive technologies can be decreased by reproductive fluids. Elife 6, doi:10.7554/eLife.23670 (2017).

114 de Waal, E. et al. The cumulative effect of assisted reproduction procedures on placental development and epigenetic perturbations in a mouse model. Hum Mol Genet 24, 6975-6985, doi:10.1093/hmg/ddv400 (2015).

115 Ludwig, M. et al. Increased prevalence of imprinting defects in patients with Angelman syndrome born to subfertile couples. J Med Genet 42, 289-291, doi:10.1136/jmg.2004.026930 (2005).

116 Hyrapetian, M., Loucaides, E. M. \& Sutcliffe, A. G. Health and disease in children born after assistive reproductive therapies (ART. J Reprod Immunol 106, 21-26, doi:10.1016/j.jri.2014.08.001 (2014).

117 Weinerman, R., Ord, T., Bartolomei, M. S., Coutifaris, C. \& Mainigi, M. The superovulated environment, independent of embryo vitrification, results in low birthweight in a mouse model. Biol Reprod 97, 133-142, doi:10.1093/biolre/iox067 (2017).

118 Dankert, D. et al. Pre- and postovulatory aging of murine oocytes affect the transcript level and poly(A) tail length of maternal effect genes. PLoS One 9, e108907, doi:10.1371/journal.pone.0108907 (2014).

119 Demond, H. et al. Preovulatory Aging In Vivo and In Vitro Affects Maturation Rates, Abundance of Selected Proteins, Histone Methylation Pattern and Spindle Integrity in Murine Oocytes. PLoS One 11, e0162722, doi:10.1371/journal.pone.0162722 (2016).

120 Lu, Y. Q., He, X. C. \& Zheng, P. Decrease in expression of maternal effect gene Mater is associated with maternal ageing in mice. Mol Hum Reprod 22, 252-260, doi:10.1093/molehr/gaw001 (2016).

121 Camprubi, C. et al. Stability of genomic imprinting and gestational-age dynamic methylation in complicated pregnancies conceived following assisted reproductive technologies. Biol Reprod 89, 50, doi:10.1095/biolreprod.113.108456 (2013).

$122 \mathrm{Ji}, \mathrm{M}$. et al. ART manipulation after controlled ovarian stimulation may not increase the risk of abnormal expression and DNA methylation at some CpG sites of H19,IGF2 and SNRPN in foetuses: a pilot study. Reprod Biol Endocrinol 16, 63, doi:10.1186/s12958-018-0344-z (2018).

123 White, C. R. et al. High Frequency of Imprinted Methylation Errors in Human Preimplantation Embryos. Sci Rep 5, 17311, doi:10.1038/srep17311 (2015).

124 Conradt, E. et al. Incorporating epigenetic mechanisms to advance fetal programming theories. Dev Psychopathol 30, 807-824, doi:10.1017/S0954579418000469 (2018).

125 Han, L. et al. Embryonic defects induced by maternal obesity in mice derive from Stella insufficiency in oocytes. Nat Genet 50, 432-442, doi:10.1038/s41588-018-0055-6 (2018).

Demonstrates that a maternal environmental insult may affect genomic integrity, epigenetic marking and developmental competence in cleavage stage of offspring.

126 Tserga, A., Binder, A. M. \& Michels, K. B. Impact of folic acid intake during pregnancy on genomic imprinting of IGF2/H19 and 1-carbon metabolism. FASEB J 31, 5149-5158, doi:10.1096/fj.201601214RR (2017).

127 Motzek, A. et al. Abnormal Hypermethylation at Imprinting Control Regions in Patients with SAdenosylhomocysteine Hydrolase (AHCY) Deficiency. PLoS One 11, e0151261, doi:10.1371/journal.pone.0151261 (2016). 
128 Amarasekera, M. et al. Genome-wide DNA methylation profiling identifies a folate-sensitive region of differential methylation upstream of ZFP57-imprinting regulator in humans. FASEB $J$ 28, 4068-4076, doi:10.1096/fj.13-249029 (2014).

129 Kessler, N. J., Waterland, R. A., Prentice, A. M. \& Silver, M. J. Establishment of environmentally sensitive DNA methylation states in the very early human embryo. Sci Adv 4, eaat2624, doi:10.1126/sciadv.aat2624 (2018).

Analysis of metastable epialleles in a rural Gambian population demonstrates epigenetic sensitivity to season of birth in early embryonic development.

130 Van de Pette, M. et al. Visualizing Changes in Cdkn1c Expression Links Early-Life Adversity to Imprint Mis-regulation in Adults. Cell Rep 18, 1090-1099, doi:10.1016/j.celrep.2017.01.010 (2017).

Demonstrates in a mouse model that maternal dietary change promotes transient alteration in DNA methylation and enduring mis-expression of an imprinted gene.

131 Ivanova, E., Chen, J. H., Segonds-Pichon, A., Ozanne, S. E. \& Kelsey, G. DNA methylation at differentially methylated regions of imprinted genes is resistant to developmental programming by maternal nutrition. Epigenetics 7, 1200-1210, doi:10.4161/epi.22141 (2012).

132 Heo, J. et al. Sirt1 Regulates DNA Methylation and Differentiation Potential of Embryonic Stem Cells by Antagonizing Dnmt3l. Cell Rep 18, 1930-1945, doi:10.1016/j.celrep.2017.01.074 (2017).

133 Kim, J. H. et al. Perinatal bisphenol A exposure promotes dose-dependent alterations of the mouse methylome. BMC Genomics 15, 30, doi:10.1186/1471-2164-15-30 (2014).

134 Kochmanski, J. J. et al. Longitudinal Effects of Developmental Bisphenol A Exposure on EpigenomeWide DNA Hydroxymethylation at Imprinted Loci in Mouse Blood. Environ Health Perspect 126, 077006, doi:10.1289/EHP3441 (2018).

135 Susiarjo, M., Sasson, I., Mesaros, C. \& Bartolomei, M. S. Bisphenol a exposure disrupts genomic imprinting in the mouse. PLoS Genet 9, e1003401, doi:10.1371/journal.pgen.1003401 (2013).

136 Trapphoff, T., Heiligentag, M., El Hajj, N., Haaf, T. \& Eichenlaub-Ritter, U. Chronic exposure to a low concentration of bisphenol A during follicle culture affects the epigenetic status of germinal vesicles and metaphase II oocytes. Fertil Steril 100, 1758-1767 e1751, doi:10.1016/j.fertnstert.2013.08.021 (2013).

137 Li, Y., Duan, F., Zhou, X., Pan, H. \& Li, R. Differential responses of GC1 spermatogonia cells to high and low doses of bisphenol A. Mol Med Rep 18, 3034-3040, doi:10.3892/mmr.2018.9256 (2018).

138 Junge, K. M. et al. MEST mediates the impact of prenatal bisphenol A exposure on long-term body weight development. Clin Epigenetics 10, 58, doi:10.1186/s13148-018-0478-z (2018).

139 Ding, Z. M. et al. Bisphenol AF negatively affects oocyte maturation of mouse in vitro through increasing oxidative stress and DNA damage. Chem Biol Interact 278, 222-229, doi:10.1016/j.cbi.2017.10.030 (2017).

140 Pathak, R. \& Feil, R. Environmental effects on chromatin repression at imprinted genes and endogenous retroviruses. Curr Opin Chem Biol 45, 139-147, doi:10.1016/j.cbpa.2018.04.015 (2018).

141 Meng, L. et al. Towards a therapy for Angelman syndrome by targeting a long non-coding RNA. Nature 518, 409-412, doi:10.1038/nature13975 (2015).

142 Kim, Y. et al. Targeting the histone methyltransferase G9a activates imprinted genes and improves survival of a mouse model of Prader-Willi syndrome. Nat Med 23, 213-222, doi:10.1038/nm.4257 (2017).

Proof-of-principal mouse study identifying small molecules that selectively reduced H3K9me2 at PWS-IC and highlighting a potential therapy for PWS.

143 Huang, H. S. et al. Topoisomerase inhibitors unsilence the dormant allele of Ube3a in neurons. Nature 481, 185-189, doi:10.1038/nature10726 (2011).

144 Lei, Y. et al. Targeted DNA methylation in vivo using an engineered dCas9-MQ1 fusion protein. Nat Commun 8, 16026, doi:10.1038/ncomms16026 (2017).

145 Cerrato, F. et al. Different mechanisms cause imprinting defects at the IGF2/H19 locus in BeckwithWiedemann syndrome and Wilms' tumour. Hum Mol Genet 17, 1427-1435, doi:10.1093/hmg/ddn031 (2008).

146 Kagami, M. et al. Deletions and epimutations affecting the human 14q32.2 imprinted region in individuals with paternal and maternal upd(14)-like phenotypes. Nat Genet 40, 237-242, doi:10.1038/ng.2007.56 (2008).

147 Azzi, S. et al. Complex tissue-specific epigenotypes in Russell-Silver Syndrome associated with 11p15 ICR1 hypomethylation. Hum Mutat 35, 1211-1220, doi:10.1002/humu.22623 (2014).

148 Nazlican, H. et al. Somatic mosaicism in patients with Angelman syndrome and an imprinting defect. Hum Mol Genet 13, 2547-2555, doi:10.1093/hmg/ddh296 (2004).

149 Weksberg, R. et al. Discordant KCNQ1OT1 imprinting in sets of monozygotic twins discordant for Beckwith-Wiedemann syndrome. Hum Mol Genet 11, 1317-1325 (2002).

150 Riess, A. et al. First report on concordant monozygotic twins with Silver-Russell syndrome and ICR1 hypomethylation. Eur J Med Genet 59, 1-4, doi:10.1016/j.ejmg.2015.12.003 (2016). 
151 Bliek, J. et al. Lessons from BWS twins: complex maternal and paternal hypomethylation and a common source of haematopoietic stem cells. Eur J Hum Genet 17, 1625-1634, doi:10.1038/ejhg.2009.77 (2009).

152 Greenberg, M. V. et al. Transient transcription in the early embryo sets an epigenetic state that programs postnatal growth. Nat Genet 49, 110-118, doi:10.1038/ng.3718 (2017).

Demonstrates that transient transcription in pre-implantation embryo sets an epigenetic state that programs postnatal growth.

153 Probst, A. V. et al. A strand-specific burst in transcription of pericentric satellites is required for chromocenter formation and early mouse development. Dev Cell 19, 625-638, doi:10.1016/j.devcel.2010.09.002 (2010).

154 De Iaco, A. et al. DUX-family transcription factors regulate zygotic genome activation in placental mammals. Nat Genet 49, 941-945, doi:10.1038/ng.3858 (2017).

155 Nativio, R. et al. Disruption of genomic neighbourhood at the imprinted IGF2-H19 locus in BeckwithWiedemann syndrome and Silver-Russell syndrome. Hum Mol Genet 20, 1363-1374, doi:10.1093/hmg/ddr018 (2011).

156 Temple, I. K., Mackay, D. J. G. \& Docherty, L. E. in GeneReviews((R)) (eds M. P. Adam et al.) (1993).

157 Mackay, D. J. \& Temple, I. K. Transient neonatal diabetes mellitus type 1. Am J Med Genet C Semin Med Genet 154C, 335-342, doi:10.1002/ajmg.c.30272 (2010).

158 Mackay, D., Bens, S., Perez de Nanclares, G., Siebert, R. \& Temple, I. K. Clinical utility gene card for: Transient Neonatal Diabetes Mellitus, 6q24-related. Eur J Hum Genet 22, doi:10.1038/ejhg.2014.27 (2014).

159 Mackay, D. J. et al. A maternal hypomethylation syndrome presenting as transient neonatal diabetes mellitus. Hum Genet 120, 262-269, doi:10.1007/s00439-006-0205-2 (2006).

160 Wakeling, E. L. et al. Diagnosis and management of Silver-Russell syndrome: first international consensus statement. Nat Rev Endocrinol 13, 105-124, doi:10.1038/nrendo.2016.138 (2017).

161 Begemann, M., Spengler, S., Kordass, U., Schroder, C. \& Eggermann, T. Segmental maternal uniparental disomy 7q associated with DLK1/GTL2 (14q32) hypomethylation. Am J Med Genet A 158A, 423428, doi:10.1002/ajmg.a.34412 (2012).

162 Barel, O. et al. Maternally inherited Birk Barel mental retardation dysmorphism syndrome caused by a mutation in the genomically imprinted potassium channel KCNK9. Am J Hum Genet 83, 193-199, doi:10.1016/j.ajhg.2008.07.010 (2008).

163 Brioude, F. et al. Expert consensus document: Clinical and molecular diagnosis, screening and management of Beckwith-Wiedemann syndrome: an international consensus statement. Nat Rev Endocrinol 14, 229-249, doi:10.1038/nrendo.2017.166 (2018).

164 Ogata, T. \& Kagami, M. Kagami-Ogata syndrome: a clinically recognizable upd(14)pat and related disorder affecting the chromosome 14q32.2 imprinted region. J Hum Genet 61, 87-94, doi:10.1038/jhg.2015.113 (2016).

165 Kagami, M. et al. Comprehensive clinical studies in 34 patients with molecularly defined UPD(14)pat and related conditions (Kagami-Ogata syndrome). Eur J Hum Genet 23, 1488-1498, doi:10.1038/ejhg.2015.13 (2015).

166 Geoffron, S. et al. Chromosome 14q32.2 Imprinted Region Disruption as an Alternative Molecular Diagnosis of Silver-Russell Syndrome. J Clin Endocrinol Metab 103, 2436-2446, doi:10.1210/jc.2017-02152 (2018).

167 Kagami, M. et al. Temple syndrome: comprehensive molecular and clinical findings in 32 Japanese patients. Genet Med 19, 1356-1366, doi:10.1038/gim.2017.53 (2017).

168 Ioannides, Y., Lokulo-Sodipe, K., Mackay, D. J., Davies, J. H. \& Temple, I. K. Temple syndrome: improving the recognition of an underdiagnosed chromosome 14 imprinting disorder: an analysis of 51 published cases. J Med Genet 51, 495-501, doi:10.1136/jmedgenet-2014-102396 (2014).

169 Driscoll, D. J., Miller, J. L., Schwartz, S. \& Cassidy, S. B. in GeneReviews((R)) (eds M. P. Adam et al.) (1993).

170 Deal, C. L. et al. GrowthHormone Research Society workshop summary: consensus guidelines for recombinant human growth hormone therapy in Prader-Willi syndrome. J Clin Endocrinol Metab 98, E10721087, doi:10.1210/jc.2012-3888 (2013).

171 Buiting, K. Prader-Willi syndrome and Angelman syndrome. Am J Med Genet C Semin Med Genet 154C, 365-376, doi:10.1002/ajmg.c.30273 (2010).

172 Baple, E. L. et al. An atypical case of hypomethylation at multiple imprinted loci. Eur J Hum Genet 19, 360-362, doi:10.1038/ejhg.2010.218 (2011).

173 Dagli, A. I., Mueller, J. \& Williams, C. A. in GeneReviews((R)) (eds M. P. Adam et al.) (1993).

174 Bird, L. M. Angelman syndrome: review of clinical and molecular aspects. Appl Clin Genet 7, 93-104, doi:10.2147/TACG.S57386 (2014). 
175 Abreu, A. P., Macedo, D. B., Brito, V. N., Kaiser, U. B. \& Latronico, A. C. A new pathway in the control of the initiation of puberty: the MKRN3 gene. J Mol Endocrinol 54, R131-139, doi:10.1530/JME-140315 (2015).

176 Fountain, M. D. \& Schaaf, C. P. Prader-Willi Syndrome and Schaaf-Yang Syndrome: Neurodevelopmental Diseases Intersecting at the MAGEL2 Gene. Diseases 4, doi:10.3390/diseases4010002 (2016).

177 Mantovani, G. et al. Diagnosis and management of pseudohypoparathyroidism and related disorders: first international Consensus Statement. Nat Rev Endocrinol 14, 476-500, doi:10.1038/s41574-018-0042-0 (2018).

178 Maupetit-Mehouas, S. et al. Simultaneous hyper- and hypomethylation at imprinted loci in a subset of patients with GNAS epimutations underlies a complex and different mechanism of multilocus methylation defect in pseudohypoparathyroidism type 1b. Hum Mutat 34, 1172-1180, doi:10.1002/humu.22352 (2013).

179 Perez-Nanclares, G. et al. Detection of hypomethylation syndrome among patients with epigenetic alterations at the GNAS locus. J Clin Endocrinol Metab 97, E1060-1067, doi:10.1210/jc.2012-1081 (2012).

180 Mulchandani, S. et al. Maternal uniparental disomy of chromosome 20: a novel imprinting disorder of growth failure. Genet Med 18, 309-315, doi:10.1038/gim.2015.103 (2016).

181 Kawashima, S. et al. Maternal Uniparental Disomy for Chromosome 20: Physical and Endocrinological Characteristics of Five Patients. J Clin Endocrinol Metab 103, 2083-2088, doi:10.1210/jc.2017-02780 (2018).

182 Popp, C. et al. Genome-wide erasure of DNA methylation in mouse primordial germ cells is affected by AID deficiency. Nature 463, 1101-1105, doi:10.1038/nature08829 (2010).

183 Chen, T., Ueda, Y., Dodge, J. E., Wang, Z. \& Li, E. Establishment and maintenance of genomic methylation patterns in mouse embryonic stem cells by Dnmt3a and Dnmt3b. Mol Cell Biol 23, 5594-5605 (2003).

184 Begemann, M. et al. Silver-Russell patients showing a broad range of ICR1 and ICR2 hypomethylation in different tissues. Clin Genet 80, 83-88, doi:10.1111/j.1399-0004.2010.01514.x (2011).

185 Akoury, E. et al. Live births in women with recurrent hydatidiform mole and two NLRP7 mutations. Reprod Biomed Online 31, 120-124, doi:10.1016/j.rbmo.2015.03.011 (2015).

186 Caliebe, A. et al. A familial disorder of altered DNA-methylation. J Med Genet 51, 407-412, doi:10.1136/jmedgenet-2013-102149 (2014).

187 Li, E., Beard, C. \& Jaenisch, R. Role for DNA methylation in genomic imprinting. Nature 366, 362365, doi:10.1038/366362a0 (1993).

188 Howell, C. Y. et al. Genomic imprinting disrupted by a maternal effect mutation in the Dnmt1 gene. Cell 104, 829-838 (2001).

189 Reese, K. J., Lin, S., Verona, R. I., Schultz, R. M. \& Bartolomei, M. S. Maintenance of paternal methylation and repression of the imprinted $\mathrm{H} 19$ gene requires MBD3. PLoS Genet 3, e137, doi:10.1371/journal.pgen.0030137 (2007).

190 Ma, P., Lin, S., Bartolomei, M. S. \& Schultz, R. M. Metastasis tumor antigen 2 (MTA2) is involved in proper imprinted expression of H19 and Peg3 during mouse preimplantation development. Biol Reprod 83, 1027-1035, doi:10.1095/biolreprod.110.086397 (2010).

191 Wu, M. Y., Tsai, T. F. \& Beaudet, A. L. Deficiency of Rbbp1/Arid4a and Rbbp1l1/Arid4b alters epigenetic modifications and suppresses an imprinting defect in the PWS/AS domain. Genes Dev 20, 28592870, doi:10.1101/gad.1452206 (2006).

192 Judson, H., Hayward, B. E., Sheridan, E. \& Bonthron, D. T. A global disorder of imprinting in the human female germ line. Nature 416, 539-542, doi:10.1038/416539a (2002).

193 Li, L., Baibakov, B. \& Dean, J. A subcortical maternal complex essential for preimplantation mouse embryogenesis. Dev Cell 15, 416-425, doi:10.1016/j.devcel.2008.07.010 (2008).

194 Wu, X. et al. Zygote arrest 1 (Zar1) is a novel maternal-effect gene critical for the oocyte-to-embryo transition. Nat Genet 33, 187-191, doi:10.1038/ng1079 (2003).

195 Gowher, H., Stuhlmann, H. \& Felsenfeld, G. Vezf1 regulates genomic DNA methylation through its effects on expression of DNA methyltransferase Dnmt3b. Genes Dev 22, 2075-2084, doi:10.1101/gad.1658408 (2008).

196 Mould, A. W. et al. Smchd1 regulates a subset of autosomal genes subject to monoallelic expression in addition to being critical for X inactivation. Epigenetics Chromatin 6, 19, doi:10.1186/1756-8935-6-19 (2013).

197 Kim, J. D., Hinz, A. K., Choo, J. H., Stubbs, L. \& Kim, J. YY1 as a controlling factor for the Peg3 and Gnas imprinted domains. Genomics 89, 262-269, doi:10.1016/j.ygeno.2006.09.009 (2007).

198 Prokhortchouk, A. et al. Kaiso-deficient mice show resistance to intestinal cancer. Mol Cell Biol 26, 199-208, doi:10.1128/MCB.26.1.199-208.2006 (2006).

199 Bohne, F. et al. Kaiso mediates human ICR1 methylation maintenance and H19 transcriptional fine regulation. Clin Epigenetics 8, 47, doi:10.1186/s13148-016-0215-4 (2016). 
200 Engel, N., West, A. G., Felsenfeld, G. \& Bartolomei, M. S. Antagonism between DNA hypermethylation and enhancer-blocking activity at the H19 DMD is uncovered by CpG mutations. Nat Genet 36, 883-888, doi:10.1038/ng1399 (2004).

201 Sparago, A. et al. Microdeletions in the human H19 DMR result in loss of IGF2 imprinting and Beckwith-Wiedemann syndrome. Nat Genet 36, 958-960, doi:10.1038/ng1410 (2004).

202 Sparago, A. et al. Mechanisms causing imprinting defects in familial Beckwith-Wiedemann syndrome with Wilms' tumour. Hum Mol Genet 16, 254-264, doi:10.1093/hmg/ddl448 (2007).

203 Kim, J. D. et al. Rex1/Zfp42 as an epigenetic regulator for genomic imprinting. Hum Mol Genet 20, 1353-1362, doi:10.1093/hmg/ddr017 (2011).

204 Nichols, J. et al. Formation of pluripotent stem cells in the mammalian embryo depends on the POU transcription factor Oct4. Cell 95, 379-391 (1998).

205 Hori, N. et al. A dyad oct-binding sequence functions as a maintenance sequence for the unmethylated state within the H19/Igf2-imprinted control region. $J$ Biol Chem 277, 27960-27967, doi:10.1074/jbc.M202280200 (2002).

206 Abi Habib, W. et al. Extensive investigation of the IGF2/H19 imprinting control region reveals novel OCT4/SOX2 binding site defects associated with specific methylation patterns in Beckwith-Wiedemann syndrome. Hum Mol Genet 23, 5763-5773, doi:10.1093/hmg/ddu290 (2014).

207 Avilion, A. A. et al. Multipotent cell lineages in early mouse development depend on SOX2 function. Genes Dev 17, 126-140, doi:10.1101/gad.224503 (2003).

\section{Acknowledgements}

The authors thank F. Cerrato, M. V. Cubellis and A. Sparago for careful reading of the manuscript. The authors apologize to all authors of studies that could not be cited due to the concise nature of this Review. Individual authors would like to thank the following funders for research support: MIUR PRIN 2015 JHLY35, Telethon-Italia GGP15131 and AIRC IG18671 (A. R.); the Deutsche Forschungsgemeinschaft (DFG), EG110/15-1 (T. E.); Spanish Ministry of Economy and Competitiveness (MINECO; BFU2014-53093-R and BFU2017-85571-R) to D. M., co-funded with the European Union Regional Development Fund (FEDER). E. R. M. acknowledges support from NIHR Cambridge Biomedical Research Centre and a NIHR Senior Investigator Award. The University of Cambridge has received salary support in respect of E. R. M. from the NHS in the East of England through the Clinical Academic Reserve. The views expressed are those of the authors and not necessarily those of the NIHR, NHS or Department of Health. 


\section{Box 1 | Epigenetic mosaicism in imprinting disorders.}

Numerous patients with imprinting disorders, with or without MLID, have somatic mosaicism, in which tissues contains cells with imprinting aberrations as well as those with appropriate allelic methylation. Mosaicism is observed with all types of primary and secondary epimutations, with the exception of erasure and establishment errors (Fig. 4), indicating a more common post-zygotic aetiology ${ }^{36}$. In principle, the developmental period immediately prior to implantation, when the embryonic epigenome is reprogrammed, is particularly vulnerable. During this time, failure to selectively protect imprints may result in hypomethylation in individual cells and their progeny. If the event occurs late in pre-implantation development, after lineage commitment, tissue-specific epimutations may result. Conversely, failure to preserve imprints from the substantial remethylation that occurs post-implantation may give rise to mosaic hypermethylation; this may account for the IC1 hypermethylation seen in $\mathrm{BWS}^{28,145}$, and imprinted gene-DMR hypermethylation in Kagami-Ogata syndrome ${ }^{146}$.

Patients with SRS or BWS often present with body asymmetry, a feature accredited to mosaicism, with recent mouse models for these two imprinting disorders identifying mosaicism in bilateral organs with asymmetric growth ${ }^{100}$. Mosaic $H 19$ hypomethylation is common in SRS, for which severity differs markedly between patients $^{147}$. Detailed studies in another imprinting disorder, Angelman Sydrome, explored the timing of such an event. In a female patient with mosaic SNURF hypomethylation, X-chromosome analysis showed that cells with the imprinting defect had either the paternally-derived or maternally-derived $X$ chromosome inactivated, suggesting that the insult occurred before $X$-inactivation and implantation ${ }^{148}$. In principle, somatic imprinting errors may occur at any time in dividing cells. Immediately following replication, the methylation pattern on the template strand is recognized by the UHRF1-DNMT1 maintenance methyltransferase complex and copied onto the daughter strand. A failure to recognize or copy this pattern will result in a sustained hemimethylated profile that will segregate in subsequent cell divisions in a tissue-restricted manner.

A phenomenon related to epigenetic mosaicism is represented by discordant monozygotic twins. Discordant monozygotic twins, whereby one twin has the disorder (nearly always female and often with MLID) and the other is healthy, are over-represented in patients with $\mathrm{BWS}^{36,37,39,149}$ and $\mathrm{SRS}^{150}$. suggesting that 
monozygotic twinning is connected with epigenetic disturbances in early development. The occasional presence of mild clinical features of BWS and intermediate methylation disturbance in an unaffected $\operatorname{twin}^{151}$ supports the hypothesis that imprinting centre epimutations precede and possibly trigger the twinning process in the early embryo.

\section{Box 2 | Transient imprinting}

A transient form of imprinting has been described in both mouse and human preimplantation embryos ${ }^{5,51,152}$ where DNA methylation is either lost on the maternal alleles or acquired by the paternal alleles post implantation. At the Gpr1/Zdbf2 locus, transient monoallelic expression of Gpr1-as1 mediates the accumulation of methylation at the Zdbf2 DMR, whose stable maintenance in adult somatic tissues regulates $Z d b f 2$ allelic expression ${ }^{152}$. More recently, widespread transient imprinting derived from oocyte-specific methylation has been demonstrated in human placenta $^{21}$. Epigenetic marks other than DNA methylation may also mediate transient imprinting, although this has not been reported in humans ${ }^{26}$. In mouse morula, some loci that display maternal allele-specific histone 3 lysine 27 trimethylation (H3K27me3) marks are expressed from their paternal alleles. This form of imprinted expression is largely lost later in development in the embryonic cell lineage but is retained at a few loci in extra-embryonic tissues. Further studies are needed to determine if this form of DNA methylation imprinting is conserved in other species and what its impact is on gene expression and phenotypes at later developmental stages. It is possible that transient and DNA methylation-independent monoallelic expression control the establishment of secondary gDMRs and consequently lead to a more stable imprinted expression in somatic tissues.

\section{Box 3 | Zygotic genome activation}

Epigenetic reprogramming and zygotic genome activation (ZGA) are intimately linked in the early embryo (see the figure; maternal (red line), early zygotic (blue line) and embryonic (black line) transcripts are shown). Approximate timing (days) of human cleavage-stage divisions and blastulation are shown. Upon maturation, the oocyte ceases transcription and translation, which do not resume in human embryo until around the 8-cell stage; therefore, the early embryo relies substantially on maternally 
provided oocyte protein and RNA. From the time of fertilization, maternal RNA is progressively degraded. The paternal genome supports an early wave of transcription (see the figure; blue line) that is essential for major ZGA ${ }^{153}$.

In the 1-cell embryo, the maternally-derived histones that replace sperm protamines do not at first establish the patterns of euchromatin and heterochromatin normally seen in somatic cells, and as a result, chromatin on the paternal genome remains atypically accessible. The paternal genome supports low-level transcription of sequences normally repressed within heterochromatin, such as retroviral repeats, and pioneer factors like DUX $4^{154}$. Pioneer factors support transcription of cleavagestage transcription factors that trigger major ZGA. Upon ZGA the genome attains a more somatic organisation, blocking the return to the permissive, early pattern of transcription.

Fig. 1 | The imprinted 11p15.5 region as an example of epigenetic error in imprinting disorders. a | Model of the 11p15.5 region represented as alternative chromatin loops on the maternal and paternal chromosomes. The model is based on the results of chromatin conformation capture studies in human cells ${ }^{22,23}$. Loops anchors occur at CTCF-cohesin binding sites. On the maternal chromosome (red line), a loop is formed between a distal region (HIDAD) located at $1.72 \mathrm{Mb}$ and the unmethylated IC1. On the paternal chromosome (blue line), the formation of this loop is prevented by IC1 methylation and an alternative one is formed between HIDAD and the IGF2 promoter. Alternative loops may facilitate differential activation of $H 19$ and IGF2 by common enhancers on the maternal and paternal chromosomes, respectively ${ }^{155}$. b | Chromosome interactions and gene expression changes predicted by the looping model as consequence of IC1 LOM in SRS ${ }^{155}$. H19 is activated and IGF2 silenced on both parental chromosomes. c | Chromosome interactions and gene expression changes predicted by the looping model as consequence of IC1 GOM in BWS ${ }^{155}$. H19 is silenced and IGF2 activated on both parental chromosomes. Chromosome distances are not in scale.

Fig. 2 | Chromosome 11p15.5 - an example of an imprinted gene cluster. Within the telomeric domain, enhancers (green ovals) direct transcription of the long non-coding RNA (IncRNA) H19 and the intragenic microRNA (miRNA) miR-675 on the maternal chromosome (red line) and that of the growth factor gene IGF2 and the 
intragenic miR-483 on the paternal chromosome (blue line). The imprinting centre (IC) of the telomeric domain (IC1; inset panel), also known as H19/IGF2 intergenic differentially methylated region (DMR), contains tandem repeats (light red and blue rectangles) and is bound by the transcription factors (TFS) CTCF, POU5F1 and SOX2, which maintain the unmethylated status of the maternal allele, whereas ZFP57 maintains the methylated status of the paternal allele. IC1 and IC2 are also characterized by different chromatin configurations on parental chromosomes, with repressive histone marks, such as H3K9me2, H3K9me3 and H4K2Ome3 on the methylated allele, and permissive histone marks, such as H3K4me2 and H3K4me3, on the unmethylated allele. Secondary DMRs (H19 promoter (prom), IGF2 DMR0 and IGF2 DMR2) are paternally methylated. The imprinting centre of the centromeric domain (IC2), also known as KCNQ1OT1:TSS-DMR, is maternally methylated and directs maternal-specific expression of KCNQ1 and the cell cycle regulator CDKN1C. On the paternal allele, a IncRNA intragenic to KCNQ1 (KCNQ1OT1) is transcribed (wavy blue lines), suppressing in cis the expression of coding genes in the region. IC2 methylation and silencing of the KCNQ1OT1 promoter are maintained through interaction with ZFP57 on the maternal chromosome, while as yet uncharacterized TFs sustain KCNQ1OT1 transcription on the paternal allele. Active alleles are represented with red (maternal) and blue (paternal) oblongs, inactive alleles with grey oblongs.

Fig. 3 | The life cycle of imprints. DNA methylation reprogramming during human development. Methylation of imprinting centres (dashed black line) is erased more slowly than that of the rest of the genome (black line) in PGCs and re-established with different kinetics in male (paternal imprinting centres, dashed blue line; whole genome, blue line) and female (maternal imprinting centres, dashed red line; whole genome, red line) germ cells. After fertilization, the maternally and paternally derived genomes are widely demethylated, while differential methylation between maternal and paternal imprinting centre alleles (50\% level) is maintained pre- and postimplantation. Factors and events involved in each stage, $5 \mathrm{mC}$ level and approximate timing of imprint erasure, establishment and pre/post-implantation maintenance are indicated. GVs, germinal vesicles. 
Fig. 4 | Mechanisms of imprinting errors in human diseases. In each panel, normal mechanisms are on the left, defective mechanisms on the right. a | Defective IC methylation erasure in PGCs. b | Defective transcription (dashed red arrow) across imprinting centre and imprint establishment in oocyte. c | Defective oocyte factor (striked pink triangle) impacting imprint establishment in oocyte. d | Defective oocyte factor (striked pink diamond) impacting developmental competence and imprint maintenance in pre-implantation embryo. e | Defective zygotic factor (white asterisk) and imprint maintenance in pre-implantation embryo. f | Defective target site (indicated with $\mathrm{x}$ ) for transcription factor protecting methylated imprinting centre and imprint maintenance in pre-implantation embryo. g | Defective target site for transcription factor recognizing unmethylated imprinting centre and imprint maintenance in post-implantation embryo. Methylated and unmethylated imprinting centres: black / white lollipops. Mosaic methylation is indicated by grey lollipops. MLID is indicated by LOM at multiple imprinting centres. Maternally methylated imprinting centres are in red, paternally methylated imprinting centres in blue. Transacting factors are as in Fig. 1.

Fig. 5 | Modes of inheritance of phenotypes associated with imprinting errors. a | Pedigree of sporadic SRS case in which IC1 epimutation is corrected in the germline of the proband. Black lollipop shows normal full methylation of paternal IC1 in blood of I:1 and in the sperm of II:1; grey lollipop, mosaic hypomethylation of paternal IC1 in blood of II:1; b-c | Pedigrees showing autosomal dominant inheritance with parent-of-origin-dependent penetrance (paternal, associated with PWS/AS imprinting centre mutation in $b$; maternal, associated with BWS/SRS IC1 mutation in c; d | Autosomal recessive (ZFP57 mutation); e | Maternal effect (NLRP5 mutations). Colored symbols indicate: SRS cases, purple; PWS cases, brown; BWS cases, blue; TNDM cases, green.

Fig. 6 | Interaction between environmental and genetic factors and its impact on genomic imprinting. The diagram summarizes the evidences obtained in humans and animal models of interaction of environmental factors and physiopathological conditions (depicted in light blue) with gametic and zygotic factors (yellow) involved in de novo and maintenance methylation and impacting imprinting 
establishment and maintenance (pink). Continuous lines indicate functional contribution; dashed lines, functional interference.

Table 1. Imprinting disorders and their main molecular defects and clinical features.

\begin{tabular}{|c|c|c|c|c|}
\hline $\begin{array}{l}\text { Imprinting disorder } \\
\text { OMIM }\end{array}$ & Prevalence & $\begin{array}{l}\text { Chromoso } \\
\text { me(s) }\end{array}$ & Molecular defect (frequency) & Main clinical features \\
\hline $\begin{array}{l}\text { Transient neonatal } \\
\text { diabetes mellitus } \\
(\text { TNDM) } \\
601410\end{array}$ & $1 / 300.000$ & Chr 6q24 & $\begin{array}{l}\text { - upd(6)pat (41\%). } \\
\text {-Paternal duplications (29\%). } \\
\text {-PLAGL1:alt-TSS-DMR LOM } \\
(30 \%) \text { (MLID: 30\% caused by } \\
\text { pathogenic ZFP57 variants } \\
159\end{array}$ & $\begin{array}{l}\text { IUGR, transient } \\
\text { diabetes mellitus, } \\
\text { hyperglycaemia without } \\
\text { ketoacidosis, } \\
\text { macroglossia, } \\
\text { abdominal wall defects }\end{array}$ \\
\hline $\begin{array}{l}\text { Silver-Russell } \\
\text { syndrome (SRS) } \\
180860\end{array}$ & $\begin{array}{l}1 / 75.000- \\
1 / 100.000\end{array}$ & $\begin{array}{l}\text { Chr } 7 \\
\text { Chr 11p15 } \\
\text { Chr 12q14 } \\
\text { Chr 8q12 }\end{array}$ & $\begin{array}{l}\text {-upd(7)mat (5-10\% (MLID: } \\
\left.\operatorname{rare}^{161}\right) \text { ) } \\
\text {-upd(11p15)mat (rare) } \\
\text {-11p15 CNVs (<1\%) } \\
\text {-H19/IGF2:IG:DMR LOM (30- } \\
\left.\text { 60\% (MLID: 7-10\% }{ }^{37,39,147}\right) \text { ) } \\
\text {-CDKN1C, IGF2, } \\
\text { HMGA2, PLAG1 point } \\
\text { mutations (rare) }\end{array}$ & $\begin{array}{l}\text { IUGR, PNGR, relative } \\
\text { macrocephaly at birth, } \\
\text { body asymmetry, } \\
\text { prominent forehead, } \\
\text { feeding difficulties }\end{array}$ \\
\hline $\begin{array}{l}\text { Birk-Barel } \\
\text { syndrome }^{162} \\
612292\end{array}$ & unknown & Chr 8q24.3 & $\begin{array}{l}- \text { KCNK9 point mutations } \\
(100 \%)\end{array}$ & $\begin{array}{l}\text { Intellectual disability, } \\
\text { hypotonia, } \\
\text { dysmorphism }\end{array}$ \\
\hline $\begin{array}{l}\text { Beckwith- } \\
\text { Wiedemann } \\
\text { syndrome } \\
(\text { BWS) } \\
130650\end{array}$ & $1 / 15.000$ & Chr 11p15 & $\begin{array}{l}\text { - upd(11p15)pat (20\%) } \\
\text {-11p15 CNVs (2-4\%) } \\
\text { - H19/IGF2:IG:DMR GOM }{ }^{\mathrm{a}} \\
(5 \%) \\
\text { - KCNQ1OT1:TSS-DMR LOM } \\
\left.\left(50 \% \text { (MLID: } 25 \%{ }^{37,39}\right)\right) \\
\text {-CDKN1C point mutations (5\% } \\
\text { sporadic; } 40-50 \% \text { in families) }\end{array}$ & $\begin{array}{l}\text { Macroglossia, } \\
\text { exomphalos, lateralized } \\
\text { overgrowth, Wilms } \\
\text { tumour or } \\
\text { nephroblastomatosis, } \\
\text { hyperinsulinism, } \\
\text { adrenal cortex } \\
\text { cytomegaly, placental } \\
\text { mesenchymal } \\
\text { dysplasia, pancreatic } \\
\text { adenomatosis }\end{array}$ \\
\hline $\begin{array}{l}\text { Kagami-Ogata } \\
\text { syndrome (KOS14) } \\
164,165 \\
608149\end{array}$ & unknown & Chr 14q32 & $\begin{array}{l}\text {-upd(14)pat }(65 \%) \\
-14 q 32 \text { maternal deletion } \\
(20 \%) \\
- \text { MEG3/DLK1:IG-DMR GOM } \\
(15 \%)\end{array}$ & $\begin{array}{l}\text { IUGR, polyhydramnion, } \\
\text { abdominal wall defects, } \\
\text { bell-shaped thorax, } \\
\text { coat-hanger ribs }\end{array}$ \\
\hline Temple syndrome & unknown & Chr 14q32 & - upd(14)mat (29\%) & IUGR, PNGR, \\
\hline
\end{tabular}




\begin{tabular}{|c|c|c|c|c|}
\hline $\begin{array}{l}(\text { TS14) } \\
6166-1682\end{array}$ & & & $\begin{array}{l}-14 q 32 \text { paternal deletion (10\%) } \\
- \text { MEG3/DLK1:IG-DMR LOM } \\
(61 \%)\end{array}$ & $\begin{array}{l}\text { neonatal hypotonia, } \\
\text { feeding difficulties in } \\
\text { infancy, truncal obesity, } \\
\text { scoliosis, precocious } \\
\text { puberty, small feet and } \\
\text { hands }\end{array}$ \\
\hline $\begin{array}{l}\text { Prader-Willi } \\
\text { syndrome } \\
\text { (PWS) }^{169-171} \\
176270\end{array}$ & $\begin{array}{l}1 / 25.000 \\
-1 / 10.000\end{array}$ & $\begin{array}{l}\text { Chr 15q11- } \\
\text { q13 }\end{array}$ & $\begin{array}{l}\text {-15q11-q13 paternal deletion } \\
(75-80 \%) \\
\text {-Upd(15)mat }(20-25 \%) \\
\text {-SNURF:TSS-DMR GOM } \\
\left(\sim 1 \%\left(\text { MLID: } \text { rare }^{172}\right)\right)\end{array}$ & $\begin{array}{l}\text { PNGR, Intellectual } \\
\text { disability, neonatal } \\
\text { hypotonia, } \\
\text { hypogenitalism, } \\
\text { hypopigmentation, } \\
\text { obesity, hyperphagia }\end{array}$ \\
\hline $\begin{array}{l}\text { Angelman syndrome } \\
(\text { AS) })^{173,174} \\
105830\end{array}$ & $\begin{array}{l}1 / 20.000 \\
-1 / 12.000\end{array}$ & $\begin{array}{l}\text { Chr 15q11- } \\
\text { q13 }\end{array}$ & $\begin{array}{l}\text { - Maternal deletion (70-75\%) } \\
\text {-Upd(15)pat (3-7\%) } \\
\text {-SNURF:TSS-DMR LOM }{ }^{\mathrm{a}}(2- \\
\left.\left.\text { 3\% (MLID: rare }{ }^{172}\right)\right) \\
\text { - UBE3A point mutations }(10 \%)\end{array}$ & $\begin{array}{l}\text { Severe intellectual } \\
\text { disability, microcephaly, } \\
\text { no speech, unmotivated } \\
\text { laughing, ataxia, } \\
\text { seizures, scoliosis }\end{array}$ \\
\hline $\begin{array}{l}\text { Central precocious } \\
\text { puberty } 2 \text { (СРPB2) } \\
175 \\
615356\end{array}$ & Unknown & Chr 15q11.2 & $\begin{array}{l}-M K R N 3 \text { point mutations } \\
(100 \%)\end{array}$ & $\begin{array}{l}\text { Early activation of the } \\
\text { hypothalamic-pituitary- } \\
\text {-gonadal axis resulting } \\
\text { in gonadotropin- } \\
\text { dependent precocious } \\
\text { puberty }\end{array}$ \\
\hline $\begin{array}{l}\text { Schaaf-Yang } \\
\text { syndrome (SYS) } \\
615547\end{array}$ & Unknown & Chr 15q11.2 & $\begin{array}{l}- \text { MAGEL2 point mutations } \\
(100 \%)\end{array}$ & $\begin{array}{l}\text { Delayed psychomotor } \\
\text { development, } \\
\text { intellectual disability, } \\
\text { hypotonia }\end{array}$ \\
\hline $\begin{array}{l}\text { Pseudohypo- } \\
\text { parathyroidism 1A } \\
\text { (PHP1A) including } \\
\text { PHP1C }^{177} \\
103580 \\
612462\end{array}$ & Unknown & Chr 20q13: & $\begin{array}{l}\text {-GNAS inactivating variants of } \\
\text { the maternal allele }(100 \%)\end{array}$ & $\begin{array}{l}\text { Resistance to PTH and } \\
\text { other hormones, } \\
\text { Albright hereditary } \\
\text { osteodystrophy, } \\
\text { moderately reduced } \\
\text { birth weight, } \\
\text { obesity, } \\
\text { cognitive impairment } \\
\text { (70\% of patients) }\end{array}$ \\
\hline $\begin{array}{l}\text { Pseudohypo- } \\
\text { parathyroidism 1B } \\
(\mathrm{PHP1B})^{177} \\
603233\end{array}$ & Unknown & Chr 20q13 & $\begin{array}{l}\text {-20q13 maternal deletion } \\
(8.5 \%) \\
\text { - GNAS DMRs LOM }(42.5 \% ; \\
\left.\text { MLID: } 12.5 \%{ }^{178,179}\right) \\
\text {-upd(20)pat }(2.5 \%) \\
\text {-20q13 point mutations }(46.5 \%)\end{array}$ & $\begin{array}{l}\text { Resistance to PTH and } \\
\text { other hormones } \\
\text { Albright hereditary } \\
\text { osteodystrophy, } \\
\text { subcutaneous } \\
\text { ossifications, } \\
\text { feeding behaviour } \\
\text { anomalies, }\end{array}$ \\
\hline
\end{tabular}




\begin{tabular}{|c|c|c|c|c|}
\hline & & & & $\begin{array}{l}\text { abnormal growth } \\
\text { patterns }\end{array}$ \\
\hline $\begin{array}{l}\text { Pseudopseudohypo- } \\
\text { parathyroidism } \\
(\mathrm{PPHP})^{177} \\
612463\end{array}$ & Unknown & Chr 20q13 & $\begin{array}{l}\text {-GNAS inactivating variants of } \\
\text { the paternal allele }(100 \%)\end{array}$ & $\begin{array}{l}\text { Mild resistance to PTH } \\
\text { and other hormones, } \\
\text { subcutaneous } \\
\text { ossifications, birth } \\
\text { weight and length } \\
\text { restrictions }\end{array}$ \\
\hline $\begin{array}{l}\text { Progressive } \\
\text { osseous } \\
\text { heteroplasia }(\mathrm{POH}) \\
177 \\
166350\end{array}$ & Unknown & Chr 20q13 & $\begin{array}{l}\text {-GNAS inactivating variants of } \\
\text { the paternal allele }(100 \%)\end{array}$ & Ectopic ossifications \\
\hline $\begin{array}{l}\text { Mulchandani-Bhoj- } \\
\text { Conlin syndrome } \\
\text { (MBCS) }^{180,181} \\
617352\end{array}$ & Unknown & Chr 20 & - upd(20)mat (100\%) & $\begin{array}{l}\text { IUGR, PNGR, feeding } \\
\text { difficulties }\end{array}$ \\
\hline
\end{tabular}

${ }^{a}$ Imprinting defects can either be due to primary imprinting epimutations without DNA sequence alterations, or due to deletions in the imprinting center (IC) critical regions. GOM, gain of methylation; IUGR, intrauterine growth restriction; LOM, loss of methylation; PNGR, postnatal growth restriction; PTH, parathyroid hormone; UPD, uniparental disomy.

Table 2. Human germline and somatic DMRs with regulated imprinted genes.

\begin{tabular}{|l|l|l|l|l|l|l|}
\hline $\begin{array}{l}\text { HGVS approved } \\
\text { DMR name }\end{array}$ & $\begin{array}{l}\text { Previous } \\
\text { names }\end{array}$ & $\begin{array}{l}\text { Location } \\
\text { (hg19/GRCh37) }\end{array}$ & $\begin{array}{l}\text { Methylated } \\
\text { allele }\end{array}$ & $\begin{array}{l}\text { Germline } \\
\text { or } \\
\text { somatic }\end{array}$ & $\begin{array}{l}\text { Known } \\
\text { TF } \\
\text { binding } \\
\text { sites }^{c}\end{array}$ & $\begin{array}{l}\text { Cis-regulated } \\
\text { genes }\end{array}$ \\
\hline PPIEL:Ex1-DMR & & $\begin{array}{l}1: 40024626- \\
40025540\end{array}$ & $\mathrm{M}$ & $\begin{array}{l}\text { Oocyte } \\
\text { gDMR }\end{array}$ & & PPIEL \\
\hline $\begin{array}{l}\text { DIRAS3:TSS- } \\
\text { DMR }\end{array}$ & $\begin{array}{l}\text { NOEY2, } \\
\text { ARH1 }\end{array}$ & $\begin{array}{l}1: 68513430- \\
68517450\end{array}$ & $\mathrm{M}$ & $\begin{array}{l}\text { Oocyte } \\
\text { gDMR }\end{array}$ & & $\begin{array}{l}\text { DIRAS3, } \\
\text { GNG12-AS1 }\end{array}$ \\
\hline DIRAS3:Ex2- & & $\begin{array}{l}1: 68512505- \\
68513486\end{array}$ & $\mathrm{M}$ & $\begin{array}{l}\text { Oocyte } \\
\text { gDMR }\end{array}$ & ZFP57 & \\
\hline $\begin{array}{l}\text { GPR1-AS:TSS- } \\
\text { DMR }\end{array}$ & & $\begin{array}{l}2: 207114583- \\
207136544\end{array}$ & $\mathrm{M}$ & $\begin{array}{l}\text { Oocyte } \\
\text { gDMR }\end{array}$ & & $\begin{array}{l}\text { GPR1-AS, } \\
\text { ZDBF2, }\end{array}$ \\
\hline $\begin{array}{l}\text { ZDBF2/GPR1- } \\
\text { AS:IG-DMR }\end{array}$ & & $\begin{array}{l}2: 207114583- \\
207136544\end{array}$ & $\mathrm{P}$ & $\begin{array}{l}\text { Sperm } \\
\text { gDMR- } \\
\text { secondary }\end{array}$ & $\begin{array}{l}\text { CTCF, } \\
\text { RAD21 }\end{array}$ & \\
\hline $\begin{array}{l}\text { JAKMIP1:Int2- } \\
\text { DMR }\end{array}$ & & $\begin{array}{l}\text { chr4:6106594- } \\
6108185\end{array}$ & $\mathrm{M}$ & $\begin{array}{l}\text { Oocyte } \\
\text { gDMR }\end{array}$ & & \\
\hline
\end{tabular}




\begin{tabular}{|c|c|c|c|c|c|c|}
\hline $\begin{array}{l}\text { NAP1L5:TSS- } \\
\text { DMR }\end{array}$ & & $\begin{array}{l}4: 89618184- \\
89619237\end{array}$ & $\mathrm{M}$ & $\begin{array}{l}\text { Oocyte } \\
\text { gDMR }\end{array}$ & ZFP57 & NAP1L5 \\
\hline${ }^{\mathrm{a}}$ VTRNA2-1:DMR & Nc886 & $\begin{array}{l}5: 135414802- \\
135416645\end{array}$ & $M$ & $\begin{array}{l}\text { Oocyte } \\
\text { gDMR }\end{array}$ & $\begin{array}{l}\text { CTCF, } \\
\text { RAD21 }\end{array}$ & \\
\hline $\begin{array}{l}{ }^{\mathrm{a}} F A M 50 B: T S S- \\
\text { DMR }\end{array}$ & & $\begin{array}{l}\text { 6:3849082- } \\
3850359\end{array}$ & $\mathrm{M}$ & $\begin{array}{l}\text { Oocyte } \\
\text { gDMR }\end{array}$ & $\begin{array}{l}\text { CTCF, } \\
\text { RAD21 }\end{array}$ & $\begin{array}{l}\text { FAM50B, } \\
\text { PXDC1 }\end{array}$ \\
\hline $\begin{array}{l}\text { PLAGL1:alt-TSS- } \\
\text { DMR }\end{array}$ & LOT1, ZAC1 & $\begin{array}{l}6: 144328078- \\
144329888\end{array}$ & $\mathrm{M}$ & $\begin{array}{l}\text { Oocyte } \\
\text { gDMR }\end{array}$ & ZFP57 & \begin{tabular}{|l} 
Multiple \\
PLAGL1 \\
transcripts, \\
HYMAI
\end{tabular} \\
\hline IGF2R:Int2-DMR & & $\begin{array}{l}\text { 6:160426558- } \\
160427561\end{array}$ & $\mathrm{M}$ & $\begin{array}{l}\text { Oocyte } \\
\text { gDMR }\end{array}$ & & \\
\hline $\begin{array}{l}{ }^{\mathrm{a}} \text { WDR27:Int13- } \\
\text { DMR }\end{array}$ & & $\begin{array}{l}\text { 6:170054504- } \\
170055618\end{array}$ & $M$ & $\begin{array}{l}\text { Oocyte } \\
\text { gDMR }\end{array}$ & CTCF & WDR27 \\
\hline $\begin{array}{l}\text { RPS2P32:TSS- } \\
\text { DMR }\end{array}$ & & $\begin{array}{l}\text { chr7:23530017- } \\
23530976\end{array}$ & $M$ & unclear & & RPS2P32 \\
\hline $\begin{array}{l}\text { GRB10:alt-TSS- } \\
\text { DMR }\end{array}$ & & $\begin{array}{l}7: 50848726- \\
50851312\end{array}$ & $\mathrm{M}$ & $\begin{array}{l}\text { Oocyte } \\
\text { gDMR }\end{array}$ & $\begin{array}{l}\text { CTCF, } \\
\text { RAD21, } \\
\text { ZFP57 }\end{array}$ & GRB10, DDC \\
\hline $\begin{array}{l}\text { PEG10:TSS- } \\
\text { DMR }\end{array}$ & & $\begin{array}{l}7: 94285537- \\
94287960\end{array}$ & $M$ & $\begin{array}{l}\text { Oocyte } \\
\text { gDMR }\end{array}$ & & $\begin{array}{l}\text { PEG10, SGCE } \\
\text { PPP1R9A, } \\
\text { TFPI2, } \\
\text { CALCR, DLX5 }\end{array}$ \\
\hline $\begin{array}{l}\text { MEST:alt-TSS- } \\
\text { DMR }\end{array}$ & PEG1 & $\begin{array}{l}7: 130130122- \\
130134388\end{array}$ & $M$ & $\begin{array}{l}\text { Oocyte } \\
\text { gDMR }\end{array}$ & $\begin{array}{l}\text { CTCF, } \\
\text { RAD21, } \\
\text { ZFP57 }\end{array}$ & $\begin{array}{l}\text { MEST, } \\
\text { MESTIT1, } \\
\text { COPG2IT1, } \\
\text { CPA4, KLF14 }\end{array}$ \\
\hline $\begin{array}{l}{ }^{a} \text { SVOPL:alt-TSS- } \\
\text { DMR }\end{array}$ & & $\begin{array}{l}7: 138348118- \\
138349069\end{array}$ & $M$ & $\begin{array}{l}\text { Oocyte } \\
\text { gDMR }\end{array}$ & & SVOPL \\
\hline $\begin{array}{l}\text { HTR5A:TSS- } \\
\text { DMR }\end{array}$ & & $\begin{array}{l}7: 154862719- \\
154863382\end{array}$ & $\mathrm{M}$ & $\begin{array}{l}\text { Oocyte } \\
\text { gDMR }\end{array}$ & & HTR5A \\
\hline $\begin{array}{l}{ }^{\mathrm{a}} E R L I N 2: \text { Int6- } \\
\text { DMR }\end{array}$ & & $\begin{array}{l}8: 37604992- \\
37606088\end{array}$ & $\mathrm{M}$ & $\begin{array}{l}\text { Oocyte } \\
\text { gDMR }\end{array}$ & & ERLIN2 \\
\hline $\begin{array}{l}\text { PEG13:TSS- } \\
\text { DMR }\end{array}$ & $\begin{array}{l}\text { TRAPPC9 } \\
\text { intronic DMR }\end{array}$ & $\begin{array}{l}8: 141108147- \\
141111081\end{array}$ & $\mathrm{M}$ & $\begin{array}{l}\text { Oocyte } \\
\text { gDMR }\end{array}$ & $\begin{array}{l}\text { CTCF, } \\
\text { RAD21, } \\
\text { ZFP57 }\end{array}$ & $\begin{array}{l}\text { PEG13, } \\
\text { TRAPPC9, } \\
\text { KCNK9 }\end{array}$ \\
\hline $\begin{array}{l}{ }^{\mathrm{a}} F A N C C: \operatorname{In} 61- \\
\text { DMR }\end{array}$ & & $\begin{array}{l}\text { 9:98075400- } \\
98075744\end{array}$ & $M$ & $\begin{array}{l}\text { Oocyte } \\
\text { gDMR }\end{array}$ & & \\
\hline $\begin{array}{l}\text { PTCHD3:TSS- } \\
\text { DMR }\end{array}$ & & $\begin{array}{l}\text { chr10:27702514- } \\
27703363\end{array}$ & $M$ & $\begin{array}{l}\text { Oocyte } \\
\text { gDMR }\end{array}$ & & PTCHD3 \\
\hline $\begin{array}{l}\text { INPP5F:Int2- } \\
\text { DMR }\end{array}$ & INPP5FV2 & $\begin{array}{l}10: 121578046- \\
121578727\end{array}$ & $M$ & $\begin{array}{l}\text { Oocyte } \\
\text { gDMR }\end{array}$ & & INPP5FV2 \\
\hline $\begin{array}{l}\text { H19/IGF2:IG- } \\
\text { DMR }\end{array}$ & $\begin{array}{l}\text { IC1, ICR1, } \\
\text { H19 DMD }\end{array}$ & $\begin{array}{l}11: 2018812- \\
2024740\end{array}$ & $\mathrm{P}$ & $\begin{array}{l}\text { Sperm } \\
\text { gDMR }\end{array}$ & $\begin{array}{l}\text { CTCF, } \\
\text { RAD21, }\end{array}$ & $\begin{array}{l}\text { Multiple IGF2 } \\
\text { transcripts, }\end{array}$ \\
\hline
\end{tabular}




\begin{tabular}{|c|c|c|c|c|c|c|}
\hline & & & & & $\begin{array}{l}\text { ZFP57, } \\
\text { POU5F1 }\end{array}$ & $\begin{array}{l}\text { IGF2-AS, INS- } \\
\text { IGF2, miR483, } \\
\text { H19, HOTS, } \\
\text { 91H, miR675 }\end{array}$ \\
\hline IGF2:Ex9-DMR & IGF2-DMR2 & $\begin{array}{l}\text { 11:2153991- } \\
2155112\end{array}$ & $\mathrm{P}$ & $\begin{array}{l}\text { Secondary } \\
\text { DMR }\end{array}$ & & \\
\hline $\begin{array}{l}\text { IGF2:alt-TSS- } \\
\text { DMR }\end{array}$ & IGF2-DMR0 & $\begin{array}{l}11: 2168333- \\
2169768\end{array}$ & $\mathrm{P}$ & $\begin{array}{l}\text { Sperm } \\
\text { gDMR }\end{array}$ & & \\
\hline $\begin{array}{l}\text { KCNQ1OT1:TSS- } \\
\text { DMR }\end{array}$ & $\begin{array}{l}\text { IC2, ICR2, } \\
\text { KVDMR1, } \\
\text { KVLQT1, LIT1 }\end{array}$ & $\begin{array}{l}\text { 11:2719948- } \\
2722529\end{array}$ & $M$ & $\begin{array}{l}\text { Oocyte } \\
\text { gDMR }\end{array}$ & ZFP57 & $\begin{array}{l}\text { KCNQ1OT1, } \\
\text { CDKN1C, } \\
\text { PHLDA2, } \\
\text { SLC22A18, } \\
\text { KCNQ1 }\end{array}$ \\
\hline RB1:Int-DMR & & $\begin{array}{l}\text { 13:48892341- } \\
48895763\end{array}$ & $M$ & $\begin{array}{l}\text { Oocyte } \\
\text { gDMR }\end{array}$ & ZFP57 & LPAR6 \\
\hline $\begin{array}{l}\text { LPAR6:TSS- } \\
\text { DMR }\end{array}$ & & $\begin{array}{l}\text { 13:48984639- } \\
48987689\end{array}$ & $\mathrm{M}$ & $\begin{array}{l}\text { Secondary } \\
\text { DMR }\end{array}$ & & \\
\hline DLK1:Int2-DMR & & $\begin{array}{l}\text { 14: } 101193446- \\
101195447\end{array}$ & $M$ & $\begin{array}{l}\text { Secondary } \\
\text { DMR }\end{array}$ & & \\
\hline $\begin{array}{l}\text { MEG3/DLK1:IG- } \\
\text { DMR }\end{array}$ & $\begin{array}{l}\text { IG-DMR, } \\
\text { GLT2-DLK1 }\end{array}$ & $\begin{array}{l}14: 101275427- \\
101278058\end{array}$ & $P$ & $\begin{array}{l}\text { Sperm } \\
\text { gDMR }\end{array}$ & & $\begin{array}{l}\text { MEG3, DLK1, } \\
\text { MEG8, DIO3, } \\
\text { RTL1, RTL-AS, } \\
\text { MEG9, } \\
\text { SNORD113, } \\
\text { SNORD114 } \\
\text { and miRNA } \\
\text { cluster }\end{array}$ \\
\hline MEG3:TSS-DMR & GTL2 & $\begin{array}{l}14: 101290524- \\
101293978\end{array}$ & $\mathrm{P}$ & $\begin{array}{l}\text { Secondary } \\
\text { DMR }\end{array}$ & $\begin{array}{l}\text { CTCF, } \\
\text { ZFP57 }\end{array}$ & \\
\hline MEG8:Int2-DMR & & $\begin{array}{l}\text { 14:101370410- } \\
101371410\end{array}$ & $\mathrm{M}$ & $\begin{array}{l}\text { Secondary } \\
\text { DMR }\end{array}$ & $\begin{array}{l}\text { CTCF, } \\
\text { RAD21 }\end{array}$ & \\
\hline $\begin{array}{l}\text { MKRN3:TSS- } \\
\text { DMR }\end{array}$ & & $\begin{array}{l}15: 23807086- \\
23812495\end{array}$ & $M$ & $\begin{array}{l}\text { Oocyte } \\
\text { gDMR- } \\
\text { secondary } \\
\text { DMR }\end{array}$ & & \\
\hline $\begin{array}{l}\text { MAGEL2:TSS- } \\
\text { DMR }\end{array}$ & & $\begin{array}{l}15: 23892425- \\
23894029\end{array}$ & $\mathrm{M}$ & $\begin{array}{l}\text { Secondary } \\
\text { DMR }\end{array}$ & & \\
\hline NDN:TSS-DMR & & $\begin{array}{l}15: 23931451- \\
23932759\end{array}$ & $\mathrm{M}$ & $\begin{array}{l}\text { Secondary } \\
\text { DMR }\end{array}$ & & \\
\hline $\begin{array}{l}{ }^{\circ} \text { SNRPN:alt-TSS- } \\
\text { DMR }\end{array}$ & & $\begin{array}{l}15: 25068564- \\
25069481\end{array}$ & $M$ & $\begin{array}{l}\text { Secondary } \\
\text { DMR }\end{array}$ & & \\
\hline $\begin{array}{l}{ }^{\mathrm{D}} \text { SNRPN:Int1- } \\
\text { DMR1 }\end{array}$ & & $\begin{array}{l}15: 25093008- \\
25193829\end{array}$ & $\mathrm{M}$ & $\begin{array}{l}\text { Secondary } \\
\text { DMR }\end{array}$ & POU5F1 & \\
\hline${ }^{D}$ SNRPN:Int1- & & $15: 25123027-$ & $\mathrm{M}$ & Secondary & & \\
\hline
\end{tabular}




\begin{tabular}{|c|c|c|c|c|c|c|}
\hline DMR2 & & 25123905 & & DMR & & \\
\hline $\begin{array}{l}\text { SNURF:TSS- } \\
\text { DMR }\end{array}$ & & $\begin{array}{l}15: 25200004- \\
25201976\end{array}$ & M & $\begin{array}{l}\text { Oocyte } \\
\text { gDMR }\end{array}$ & YY1 & $\begin{array}{l}\text { MKRN3, } \\
\text { MAGEL2, } \\
\text { NDN, PWRN1, } \\
\text { SNRPN, IPW, } \\
\text { SNHG14, } \\
\text { SNORD116, } \\
\text { SNORD115, } \\
\text { UBE3A }\end{array}$ \\
\hline SNORD116:DMR & $\begin{array}{l}\text { SNHG14, } \\
\text { UBE3A-AS }\end{array}$ & $\begin{array}{l}15: \quad 25156289- \\
25405834\end{array}$ & $\mathrm{P}$ & $\begin{array}{l}\text { Secondary } \\
\text { DMR }\end{array}$ & & \\
\hline IGF1R:Int2-DMR & IRIAN & $\begin{array}{l}15: 99408496- \\
99409650\end{array}$ & $M$ & $\begin{array}{l}\text { Oocyte } \\
\text { gDMR }\end{array}$ & & IRIAN \\
\hline ZNF597: 3'-DMR & & $\begin{array}{l}\text { 16:3481801- } \\
3482388\end{array}$ & M & $\begin{array}{l}\text { Oocyte } \\
\text { gDMR }\end{array}$ & & $\begin{array}{l}\text { ZNF597, } \\
\text { NAA60 }\end{array}$ \\
\hline $\begin{array}{l}\text { ZNF597:TSS- } \\
\text { DMR }\end{array}$ & NAT15 & $\begin{array}{l}16: 3492828- \\
3494463\end{array}$ & $\mathrm{P}$ & $\begin{array}{l}\text { Secondary } \\
\text { DMR }\end{array}$ & & \\
\hline $\begin{array}{l}\text { ZNF331:alt-TSS- } \\
\text { DMR1 }\end{array}$ & & $\begin{array}{l}19: 54040510- \\
54042212\end{array}$ & M & $\begin{array}{l}\text { Oocyte } \\
\text { gDMR }\end{array}$ & CTCF & \\
\hline $\begin{array}{l}\text { ZNF331:alt-TSS- } \\
\text { DMR2 }\end{array}$ & & $\begin{array}{l}\text { 19:54057086- } \\
54058425\end{array}$ & $M$ & $\begin{array}{l}\text { Oocyte } \\
\text { gDMR }\end{array}$ & & \\
\hline PEG3:TSS-DMR & ZIM2, ZNF904 & $\begin{array}{l}19: 57348493- \\
57353271\end{array}$ & $M$ & $\begin{array}{l}\text { Oocyte } \\
\text { gDMR }\end{array}$ & ZFP57 & $\begin{array}{l}\text { PEG3, ZIM2, } \\
\text { MIMT1 }\end{array}$ \\
\hline $\begin{array}{l}\text { MCTS2P:TSS- } \\
\text { DMR }\end{array}$ & $\begin{array}{l}\text { psMCT1, } \\
\text { MCST2 }\end{array}$ & $\begin{array}{l}20: 30134663- \\
30135933\end{array}$ & M & $\begin{array}{l}\text { Oocyte } \\
\text { gDMR }\end{array}$ & $\overline{Y Y 1}$ & MCST2, HM13 \\
\hline NNAT:TSS-DMR & PEG5 & $\begin{array}{l}20: 36148604- \\
36156528\end{array}$ & $M$ & $\begin{array}{l}\text { Oocyte } \\
\text { gDMR }\end{array}$ & ZFP57 & NNAT, BLACP \\
\hline $\begin{array}{l}\text { L3MBTL1:alt- } \\
\text { TSS-DMR }\end{array}$ & $\begin{array}{l}\text { ZC2HC3, } \\
\text { KIAA0681 }\end{array}$ & $\begin{array}{l}20: 42142365- \\
42144040\end{array}$ & M & $\begin{array}{l}\text { Oocyte } \\
\text { gDMR }\end{array}$ & $\begin{array}{l}\text { CTCF, } \\
\text { RAD21 }\end{array}$ & $\begin{array}{l}\text { L3MBTL1, } \\
\text { SGK2 }\end{array}$ \\
\hline $\begin{array}{l}\text { GNAS- } \\
\text { NESP:TSS-DMR }\end{array}$ & NESP55 & $\begin{array}{l}20: 57414039- \\
57418612\end{array}$ & $\mathrm{P}$ & $\begin{array}{l}\text { Secondary } \\
\text { DMR }\end{array}$ & $\begin{array}{l}\text { CTCF, } \\
\text { RAD21 }\end{array}$ & $\begin{array}{l}\text { Multiple GNAS } \\
\text { transcripts, } \\
\text { miR296, } \\
\text { miR298 }\end{array}$ \\
\hline $\begin{array}{l}\text { GNAS-AS1:TSS- } \\
\text { DMR }\end{array}$ & NESP-AS & $\begin{array}{l}20: 57425649- \\
57428033\end{array}$ & M & $\begin{array}{l}\text { Oocyte } \\
\text { gDMR }\end{array}$ & $\begin{array}{l}\text { CTCF, } \\
\text { RAD21, }\end{array}$ & \\
\hline $\begin{array}{l}\text { GNAS-XL:TSS- } \\
\text { DMR }\end{array}$ & $\begin{array}{l}\text { Secretogramin } \\
\text { VI }\end{array}$ & $\begin{array}{l}20: 57428905- \\
57431463\end{array}$ & $M$ & $\begin{array}{l}\text { Oocyte } \\
\text { gDMR }\end{array}$ & ZFP57 & \\
\hline $\begin{array}{l}\text { GNAS A/B:TSS- } \\
\text { DMR }\end{array}$ & $\begin{array}{l}\text { Secretogramin } \\
\text { VI }\end{array}$ & $\begin{array}{l}20: 57463265- \\
57465201\end{array}$ & $M$ & $\begin{array}{l}\text { Oocyte } \\
\text { gDMR }\end{array}$ & & \\
\hline $\begin{array}{l}\text { WRB:alt-TSS- } \\
\text { DMR }\end{array}$ & & $\begin{array}{l}21: 40757510- \\
40758276\end{array}$ & M & $\begin{array}{l}\text { Oocyte } \\
\text { gDMR }\end{array}$ & & \\
\hline $\begin{array}{l}{ }^{a} \text { SNU13:alt-TSS- } \\
\text { DMR }\end{array}$ & NHP2L1 & $\begin{array}{l}22: 42077774- \\
42078873\end{array}$ & $M$ & $\begin{array}{l}\text { Oocyte } \\
\text { gDMR }\end{array}$ & & \\
\hline
\end{tabular}


${ }^{a}$ These imprinted DMRs show evidence for mosaicism in the general population with low frequency hypomethylation reported. ${ }^{\mathrm{b}}$ The entire $\sim 1 \mathrm{MB}$ interval between the NDN and SNURF DMRs (chr15:2411225325108042) is preferentially methylated on the maternal allele. cTranscription factor binding sites taken from: YY1 ChIP-seq ENCODE datasets (March 2012); CTCF ChIP-seq ENCODE datasets (March 2012); ZFP57 ChIP-seq dataset Imbeault et al., 2017. Nature 543:550-554; POU5F1 ChIP-seq ENCODE datasets (March 2012). HGVS, Human Genome Variation Society; M, maternal; P, paternal.

Table 3. Factors with potential roles in imprinting control.

\begin{tabular}{|c|c|c|c|}
\hline Factor & Function & Mouse knockout phenotype & $\begin{array}{l}\text { Associated imprinting } \\
\text { disorders }\end{array}$ \\
\hline $\begin{array}{ll}\text { AID } & \text { and } \\
\text { APOBEC1 } & \end{array}$ & $\begin{array}{l}\text { Possible role in active } \\
\text { demethylation in } \\
\text { PGCs }\end{array}$ & $\begin{array}{l}\text { Modest global hypermethylation } \\
\text { in deficient PGCs }{ }^{182}\end{array}$ & not reported \\
\hline TET1 and TET2 & $\begin{array}{l}\text { Implicated in } \\
\text { demethylation as they } \\
\text { have specific activity } \\
\text { for converting } 5 \mathrm{mC} \text { to } \\
5 \mathrm{hmC}\end{array}$ & $\begin{array}{l}\text { DKO mice have reduced } 5 \mathrm{hmC} \\
\text { and increased } 5 \mathrm{mC} \text { levels at } \\
\text { some imprinted loci (Mest, Peg3, } \\
\text { Igf } 2 \mathrm{r}, \mathrm{H} 19)^{45}\end{array}$ & not reported \\
\hline DNMT3A/B & $\begin{array}{l}\text { De novo DNA } \\
\text { methyltransferase }\end{array}$ & No methylation at gDMRs ${ }^{183}$ & not reported \\
\hline DNMT3L & $\begin{array}{l}\text { Associate factor for } \\
\text { DNMT3 }\end{array}$ & No methylation at gDMRs ${ }^{53}$ & $\begin{array}{lrl}\text { No pathogenic } & \text { variants } \\
\text { identified in } \text { SRS }^{184} & \end{array}$ \\
\hline KDM1B & $\begin{array}{l}\text { Oocyte-specific } \mathrm{H} 3 \mathrm{~K} 4 \\
\text { demethylase }\end{array}$ & $\begin{array}{l}\text { LOM at multiple gDMRs (Mest, } \\
\text { Grb10, Zac1, Impact, U2af1-rs1, } \\
\text { Peg10, Nnat, KvDMR1, Igf2r, } \\
\text { Gnas) }^{60,62}\end{array}$ & not reported \\
\hline KDM1A & H3K4 demethylase & $\begin{array}{l}\text { LOM at transient Cdh15 gDMRs } \\
62\end{array}$ & not reported \\
\hline NLRP7 & $\begin{array}{l}\text { NACHT, LRR and } \\
\text { PYD } \\
\text { containing protein } 7 \\
\text { potentially a SCMC } \\
\text { interacting proteins }\end{array}$ & No mouse orthologue & $\begin{array}{l}\text { Biparental hydatidiform moles } \\
\text { with complete lack of maternal } \\
\text { imprints }^{77,78 ; \quad M L I D ~ i n ~ r a r e ~} \\
\text { hypomorphs }\end{array}$ \\
\hline $\begin{array}{lr}\text { DNMT1 } & \text { (both } \\
\text { oocyte and } \\
\text { somatic } \\
\text { isoforms) }\end{array}$ & $\begin{array}{l}\text { Maintenance DNA } \\
\text { methyltransferase }\end{array}$ & $\begin{array}{l}\text { Widespread LOM during } \\
\text { embryonic cleavage stages }{ }^{187,188}\end{array}$ & BWS with IC2 LOM $^{9 /}$ \\
\hline DNMT3A/B & $\begin{array}{l}\text { De novo DNA } \\
\text { methyltransferase }\end{array}$ & No methylation at gDMRs ${ }^{54,183}$ & not reported \\
\hline ZFP57 & $\begin{array}{l}\text { KAP1 recruiting zinc- } \\
\text { finger protein }\end{array}$ & $\begin{array}{l}\text { Widespread LOM during } \\
\text { embryonic cleavage stages }^{87}\end{array}$ & TNDM patients with MLID ${ }^{93}$ \\
\hline TRIM28/KAP1 & $\begin{array}{l}\text { KRAB1-associated } \\
\text { protein repressor }\end{array}$ & $\begin{array}{l}\text { Partial LOM during embryonic } \\
\text { cleavage stages }(H 19, \text { Snrpn })^{94}\end{array}$ & $\begin{array}{l}\text { No pathogenic } \\
\text { identified in } M L I D^{36}\end{array}$ \\
\hline
\end{tabular}




\begin{tabular}{|c|c|c|c|}
\hline & complex & & \\
\hline UHRF1 & $\begin{array}{l}\text { Guides DNMT1 to } \\
\text { hemimethylated DNA } \\
\text { during replication }\end{array}$ & $\begin{array}{l}\text { Partial LOM during embryonic } \\
\text { cleavage stages (H19, KvDMR1, } \\
\text { Ig-DMR })^{95}\end{array}$ & Single case of MLID ${ }^{39}$ \\
\hline Histone H1 & Linker histones & $\begin{array}{l}\text { Triple KOs result in Partial LOM } \\
(H 19, \text { Ig-DMR })\end{array}$ & not reported \\
\hline MBD3 & $\begin{array}{l}\text { Methyl-CpG binding } \\
\text { protein }\end{array}$ & Partial LOM at $H 19^{189}$ & $\begin{array}{lrr}\text { No } & \text { pathogenic } & \text { variants } \\
\text { identified in } \text { SRS }^{184} & \end{array}$ \\
\hline MTA2 & $\begin{array}{l}\text { Metastasis tumour } \\
\text { antigen 2, member of } \\
\text { NuRD complex }\end{array}$ & Partial LOM at $H 19$ and $P e g 3^{190}$ & not reported \\
\hline $\begin{array}{l}\text { RBBP1/Arid4a } \\
\text { RBBP1L1/Arid4b }\end{array}$ & $\begin{array}{l}\text { Retinoblastoma- } \\
\text { binding proteins }\end{array}$ & LOM at Snrpn in double $\mathrm{KOs}^{191}$ & not reported \\
\hline DPPA3/STELLA & $\begin{array}{l}\text { Binds to methylated } \\
\text { and H3K9 decorated } \\
\text { gDMRs }\end{array}$ & $\begin{array}{l}\text { Partial LOM at several gDMRs } \\
\text { (Snrpn, Mest, Peg3, Nnat, } \\
\text { Peg10, H19, Rasgrf1) }\end{array}$ & $\begin{array}{lll}\text { No } & \text { pathogenic } & \text { variants } \\
\text { identified in } \text { MLID }^{147} & \end{array}$ \\
\hline NLRP2 & $\begin{array}{l}\text { NACHT, LRR and } \\
\text { PYD } \\
\text { containing } \\
\text { potentially a Scotein } 2 \\
\text { member }\end{array}$ & $\begin{array}{l}\text { Aberrant gDMRs (GOM and } \\
\text { LOM) in embryos that survive to } \\
\text { mid-gestation }\end{array}$ & $\mathrm{MLID}^{15}$ \\
\hline $\begin{array}{l}\text { KHDC3L/ } \\
\text { C6orf221/FILIA }\end{array}$ & $\begin{array}{l}\text { KH } \\
\text { Containing } 3 \text { Like, } \\
\text { Subcortical Maternal } \\
\text { Complex Member }\end{array}$ & Imprinting not assessed $^{84}$ & $\begin{array}{lr}\text { Biparental hydatidiform } & \text { moles. } \\
\text { LOM at several } & \text { DMRs } \\
\text { (KvDMR1, SNRPN, } & \text { MEST, } \\
\text { PEG3, GNAS XL, } & \text { GNAS } \\
\text { A/B) } & \\
\text { No pathogenic } & \text { variants } \\
\text { identified in MLID } & \end{array}$ \\
\hline NLRP5/MATER & Member of SCMC & Imprinting not assessed ${ }^{82}$ & $\mathrm{MLID}^{37}$ \\
\hline OOEP & Member of SCMC & Imprinting not assessed $^{193}$ & Single case of MLID ${ }^{39}$ \\
\hline PADI6 & Member of SCMC & Imprinting not assessed ${ }^{83}$ & $\mathrm{MLID}^{39}$ \\
\hline ZAR1 & $\begin{array}{l}\text { Oocyte-specific zinc } \\
\text { finger protein }\end{array}$ & Imprinting not assessed ${ }^{194}$ & Single case of MLID ${ }^{39}$ \\
\hline VEZF1 & $\begin{array}{ll}\text { Zinc } & \text { finger } \\
\text { transcription } & \text { factor } \\
\text { DB1 } & \end{array}$ & $\begin{array}{l}\text { Partial LOM at } H 19 \text { and } \operatorname{lgf} 2 r \\
\text { gDMRs }^{195}\end{array}$ & $\begin{array}{l}\text { No pathogenic identified in } \\
\text { MLID }{ }^{147}\end{array}$ \\
\hline SMCHD1 & $\begin{array}{l}\text { Structural } \\
\text { Maintenance of } \\
\text { Chromosome Flexible } \\
\text { Hinger Domain- } \\
\text { Containing protein }\end{array}$ & $\begin{array}{l}\text { LOM of secondary DMRs in } \\
\text { mouse } 7 q B 5 \text { domain }^{196}\end{array}$ & not reported \\
\hline YY1 & $\begin{array}{l}\text { Transcriptional } \\
\text { repressor protein }\end{array}$ & $\begin{array}{l}\text { Aberrant } \text { gDMRs } \quad \text { (GOM and } \\
\text { LOM) }\end{array}$ & not reported \\
\hline ZBTB33 & Zinc finger an BTB & Imprinting not assessed $^{198}$ & shRNA-targeting resulting in \\
\hline
\end{tabular}




\begin{tabular}{|c|c|c|c|}
\hline & $\begin{array}{l}\text { Domain Containing } \\
\text { transcription factor }\end{array}$ & & partial LOM at $\mathrm{H} 19^{199}$ \\
\hline CTCF & $\begin{array}{l}\text { Zinc finger protein } \\
\text { involved in chromatin } \\
\text { organisation }\end{array}$ & GOM at $H 19^{200}$ & $\begin{array}{l}\text { Microdeletions of CTCF binding } \\
\text { sites result in IC1 GOM in } \\
\text { BWS }^{28,201,202}\end{array}$ \\
\hline ZFP42/REX1 & Zinc finger protein & GOM at Peg3 and GNAS ${ }^{203}$ & not reported \\
\hline POU5F1 & $\begin{array}{l}\text { Pioneer pluripotency } \\
\text { transcription factor }\end{array}$ & Imprinting not assessed ${ }^{204}$ & $\begin{array}{l}\text { Binding site pathogenic variants } \\
\text { leads to IC1 GOM in } \\
\text { BWS }^{99,205,206}\end{array}$ \\
\hline SOX2 & $\begin{array}{l}\text { Pioneer pluripotency } \\
\text { transcription factor }\end{array}$ & Imprinting not assessed $^{201}$ & $\begin{array}{l}\text { Binding site pathogenic variants } \\
\text { leads to IC1 GOM in } \\
\text { BWS }^{99,103,205,206}\end{array}$ \\
\hline
\end{tabular}

PGCs, primordial germ cells. 


\section{Glossary}

\section{Genomic imprinting}

The epigenetic marking of a gene on the basis of parental origin, which results in monoallelic expression.

\section{Anticipation}

A phenomenon whereby the symptoms of a genetic disorder become apparent at an earlier age or with greater severity in succeeding generations.

\section{Assisted reproductive technologies}

(ART). Techniques used to achieve pregnancy during the treatment of infertility. ART covers a wide spectrum of treatments including the use of fertility drugs, intrauterine insemination and in vitro fertilization/intracytoplasmic sperm injection.

\section{Blastocyst}

Developmental stage of mammalian embryo just before implantation consisting of an inner cell mass which will form the embryo, and a cavity with an outer layer called trophoblast, which will give rise to the placenta.

\section{cis-acting element}

DNA sequence regulating the expression of a gene that is present on the same chromosome.

\section{Copy number variation}

(CNV). Type of structural variation of a chromosome consisting in duplication or deletion of DNA sequence.

\section{Endogenous retrovirus}

Repetitive genetic element present in the genome that, similarly to retroviruses, uses the activity of reverse transcriptase to move from one locus to another (also known as retrotransposons).

\section{Epiallele}


Epigenetic profile which is maintained in somatic tissues resulting in interindividual variation.

\section{Epigenome}

Chromatin modifications influencing genome function and not involving the underlying DNA sequence that can be propagated through cell division.

\section{Epigenetic reprogramming}

The erasure of pre-existing epigenetic marks that allow for subsequent remodelling of chromatin.

\section{Epimutation}

When referred to imprinting disorders, epigenetic change that affects the regulation of imprinted loci. The epimutation is primary if there is no detectable genetic cause, secondary if it is associated with a genetic cause.

\section{Imprinting disorders}

Diseases associated with disruption of imprinted gene expression that can be caused by genetic or epigenetic defects.

\section{Incomplete penetrance}

A situation in which not all individuals carrying a dominant deleterious genetic variant express the associated clinical phenotype.

\section{Gain of methylation}

(GOM). When referred to imprinting disorders, gain of methylation on the unmethylated allele of imprinting centre. It is detected in patients and causes deregulation of the imprinted genes in the domain controlled by the imprinting centre.

\section{Genome activation}

The initiation of gene expression in the developing embryo. The initial burst of expression is termed zygotic genome activation (ZGA) and is regulated by pioneer transcription factors during the oocyte-to-embryo transition. Initiation of expression in cleavage embryos is referred to as embryonic genome activation. 


\section{Germline differentially methylated region}

(gDMR): Regions of differential DNA methylation between parental alleles in somatic cells that originate from the gametes. gDMRs that survive embryonic reprogramming are generally associated with imprinted genes.

\section{Haploinsufficiency}

A situation in which half of the normal level of a gene product, usually consequence of a loss-of-function mutation, is not sufficient for the normal function.

\section{Hydatidiform mole}

Benign gestational trophoblastic disease developing during pregnancy and resulting from an abnormal fertilization. It is characterized by trophoblastic proliferation and little or no embryonic tissue. It is commonly sporadic and contains only sperm DNA. Occasionally, it can be biparental, recurrent and familial following an autosomal recessive mode of inheritance.

\section{Imprinting centre}

A function definition for gDMRs that have been shown to regulate imprinted genes expression through either genetic targeting in mouse or through mutations in patients. Also known as imprinting control region (ICR). Not all gDMRs have been shown to be imprinting centre regions.

\section{Loss of methylation}

(LOM). When referred to imprinting disorders, loss of differential imprinting centre methylation detected in patients and causing deregulation of the imprinted genes in the domain controlled by the imprinting centre.

\section{Multi-locus imprinting disturbance}

(MLID). Methylation anomalies at imprinted DMRs in patients with imprinting disorders in addition to those that are normally associated with the disease.

\section{Maternal effect gene}


A gene coding for an oocyte-derived transcript or protein that is required for the early development of the embryo.

\section{Penetrance}

Proportion of individuals in a population with a specific genotype who show an associated phenotypic trait.

\section{Primordial germ cells}

(PGCs). Stem cell-like cells found in the gonadal ridge of developing embryos that develop into gametes following sex-specific epigenetic reprogramming and meiosis.

\section{Pronucleus}

The haploid nucleus from a male or female gamete before the genetic material fuse at syngamy.

\section{Protamines}

Basic proteins that largely replace histones in the nucleus of mature sperm for more condensed DNA packaging.

\section{Secondary differentially methylated region}

A region of differential DNA methylation between parental alleles that does not originate from the germline. They are often referred to as somatic DMRs and are regulated in a hierarchical fashion by a nearby imprinting centre region.

\section{Subcortical maternal complex}

(SCMC). A large multi-protein complex comprising of NLRP5, OOEP, TLE6, PADI6 and KHDC3L that localises to the outermost regions of the cytoplasm in oocytes and excluded from regions of cell-to-cell contact in cleavage embryos.

\section{trans-acting factor}

Protein regulating the expression of a gene.

\section{Uniparental disomy}


(UPD). Genetic defect characterized by the presence of two copies of a chromosome or part of it derived from only one parent.

\section{Zygote}

A fertilized ovum before the first cell division which represents the earliest stage of embryonic development. The zygote's genome is a combination of the DNA in each gamete. 